\title{
The River Mondego terraces at the Figueira da Foz coastal area (western central Portugal): Geomorphological and sedimentological characterization of a terrace staircase affected by differential uplift and glacio-eustasy
}

\author{
Anabela M. Ramos ${ }^{\text {a,* }}$, Pedro P. Cunha ${ }^{\text {b }}$, Lúcio S. Cunha ${ }^{c}$, Alberto Gomes ${ }^{\mathrm{d}}$, Fernando C. Lopes ${ }^{\mathrm{e}}$, \\ Jan-Pieter Buylaert f,g, Andrew S. Murray ${ }^{\mathrm{g}}$ \\ a CEGOT, University of Coimbra, Portugal \\ b Department of Earth Sciences, IMAR-CMA, University of Coimbra, Portugal \\ c Department of Geography, Univ. Coimbra, CEGOT, Portugal \\ d Department of Geography, Univ. Porto, CEGOT, Portugal \\ e Department of Earth Sciences, CGUC, University of Coimbra, Portugal \\ ${ }^{\mathrm{f}}$ Radiation Research Division, Risø DTU, Denmark \\ ${ }^{g}$ Nordic Laboratory for Luminescence Dating, Aarhus University, Risø DTU, Denmark
}

\section{A R T I C L E I N F O}

\section{Article history:}

Received 29 September 2011

Received in revised form 27 March 2012

Accepted 29 March 2012

Available online 10 April 2012

\section{Keywords:}

River terraces

Uplift

Pleistocene

River Mondego

Western Iberia

\begin{abstract}
A B S T R A C T
A geomorphological and sedimentological characterization of the River Mondego terraces in the Figueira da Foz coastal area, Portugal, is presented. The relief is dominated by a Pliocene a marine sandy unit $\sim 10-15 \mathrm{~m}$ thick, reaching $250 \mathrm{~m}$ a.s.l., that covers a shore platform surface. The River Mondego has incised into the Pliocene relief and its long drainage evolution is recorded within a series of inset river terrace landforms. These river terraces are better preserved on the right-hand (northern) bank, where they form a staircase developed against the uplifted Serra da Boa Viagem structure. A set of five river terraces, represented by sedimentary deposits or erosional straths, are identified, namely: T1 at 128-125 m; T2 at 101-90 m; T3 at 70-60 m; T4 at 29-24 m; T5 at 11-10 m a.s.l. Some luminescence dating ages were obtained from the river terrace deposits: > 390 ka from the middle of $\mathrm{T} 4 ;>170 \mathrm{ka}$ from the top of $\mathrm{T} 4 ; \sim 120 \mathrm{ka}$ from the base of T5; 109 ka from T5 (average age for three samples); and $53 \pm 3 \mathrm{ka}$ from a colluvium at $35 \mathrm{~m}$ a.s.l. Some differences in altitude of the uppermost sedimentary unit and of the terraces are here interpreted as resulting from vertical displacements of active faults during the Quaternary. The main tectonic structure is the WNW-ESE trending Quiaios fault, responsible for the regional tilting towards SW. Other probably active faults and tectonic lineaments trend NNW-SSE to N-S, NNE-SSW to NE-SW and WNW-ESE. This study reports a long-term uplift rate of $0.004-0.055 \mathrm{~m} / \mathrm{ka}$ for the last $3.6 \mathrm{Ma}$, but $0.017-0.118 \mathrm{~m} / \mathrm{ka}$ for the last $\sim 1.8 \mathrm{Ma}$ (using as references, respectively, the base and the surface of the uppermost sedimentary unit). The facies associations that characterize the older terrace deposits (T1 and T2) consist of poorly sorted fluvial sandy-gravels and silts, but also some colluvium at the top of each terrace. The younger terraces (T3, T4 and T5) show better developed sedimentary structures and less sedimentary matrix; the sedimentary features are indicative of both fluvial and coastal environments (estuary and beach, as nowadays). Under conditions of continuous uplift, the episodes of river down-cutting, valley widening and aggradation in the studied area can be attributed to the rise and fall of sea-level in response to the global Quaternary climatic fluctuations. Considering the number of terraces and the dating obtained, it seems that the control of terrace genesis in this coastal area should be dominated by glacio-eustasy whereby episodic valley incision would have been determined by periods of very low sea-level, probably at 460-410 ka (T3/T4; MIS12), 200-125 ka (T4/T5; MIS6) and 100-14 ka (T5/Recent alluvial infill; late MIS5, MIS4, MIS3 and MIS2). Some sandy colluvium deposits on the slopes are probably related with mild-cold and wet climate conditions during the period 60 to $32 \mathrm{ka}$. The aeolian dunes are younger (cold to temperate dry conditions; MIS2 and MIS1).
\end{abstract}

(c) 2012 Elsevier B.V. All rights reserved.

\footnotetext{
* Corresponding author.

E-mail address: ana-baia@sapo.pt (A.M. Ramos).
}

\section{Introduction}

The interpretation of river terrace staircases in relation to causal mechanisms (tectonics, eustasy and climate) is still a subject of discussion in the international literature (e.g. Blum and Törnqvist, 
2000; Bridgland et al., 2007; Bridgland and Westaway, 2008a, 2008b; Cunha et al., 2008; Seyrek et al., 2008; Gibbard and Lewin, 2009; Westaway et al., 2009; Lewin and Gibbard, 2010). The known evolution of European rivers during the Pleistocene varies individually but is predominantly marked by several stages of episodic incision and aggradation that broadly relate to climatic changes, whilst in other settings these stages have also been related to sea-level and tectonic responses.

Within Iberia, the terrace staircases located in the lower reaches of rivers draining to the Atlantic Ocean could provide suitable archives with which to interpret the roles played by these mechanisms, and in particular glacio-eustasy. The largest and best understood river system in Portugal is the Lower River Tejo. It comprises up to six terrace levels (T1 to T6), inset below a top basin fill surface and its uppermost sedimentary unit. Absolute dating of the lower terrace levels spans the Middle to Late Pleistocene: T4 $-\sim 340$ to $\sim 150 \mathrm{ka}$; T5 -136 to $75 \mathrm{ka}$; T6 - 62 to $32 \mathrm{ka}$ (Cunha et al., 2008, 2012; Martins et al., 2009, 2010a, 2010b). The formation of the four younger terraces and the Holocene alluvial infill is interpreted to be related to cyclic glacio-eustatic fluctuations superimposed onto a long-term regional uplift trend.

The Mondego is the longest river located exclusively on Portuguese territory. It has its source $1425 \mathrm{~m}$ above (mean) sea level (a.s.l.) on the northern slopes of the Estrela Mountain Range, the highest mountain range in mainland Portugal. The Mondego flows for $234 \mathrm{~km}$ in a southwestward direction to its mouth into the Atlantic Ocean (Fig. 1), next

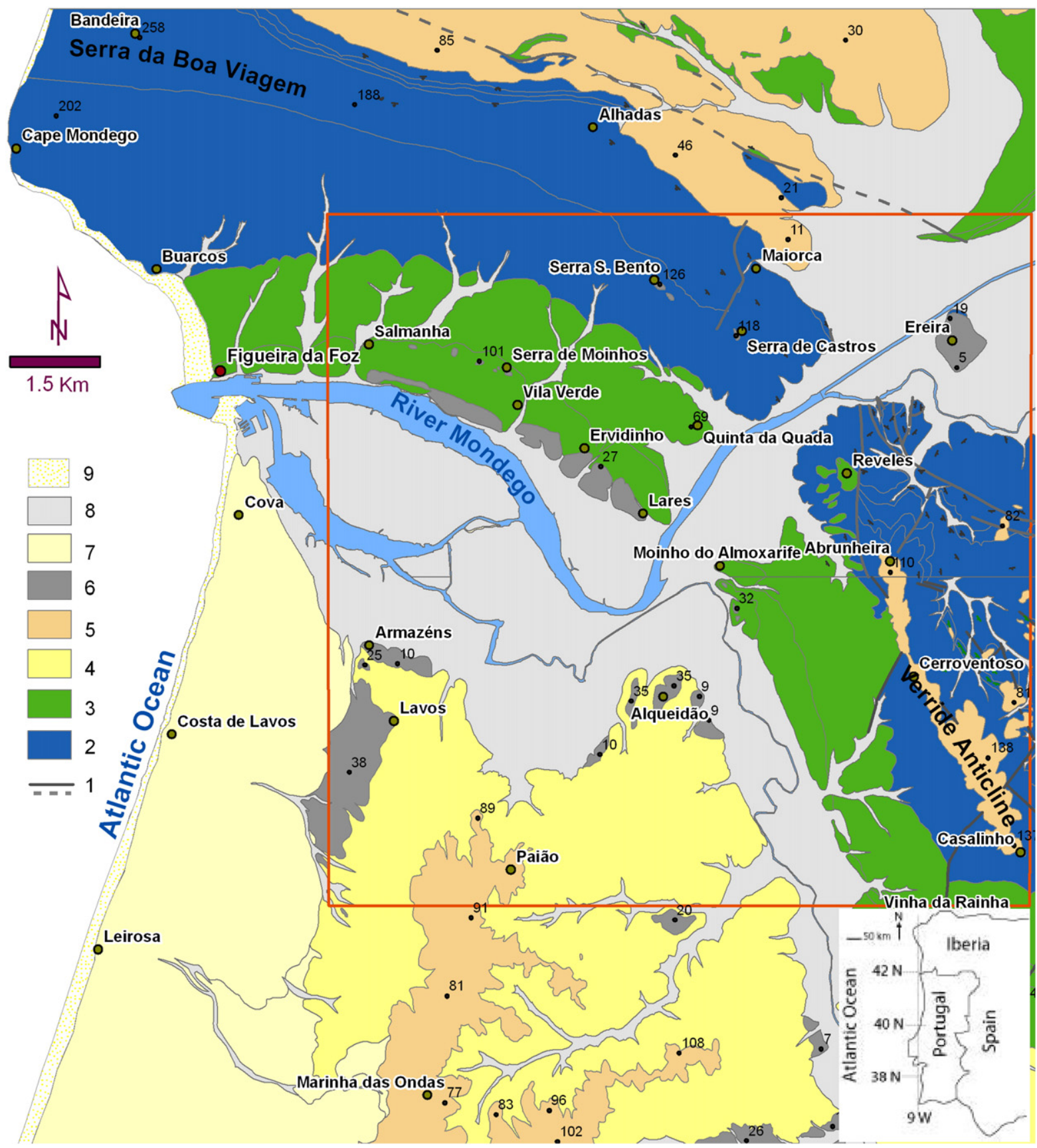

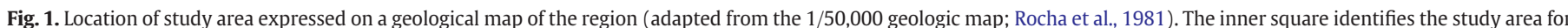

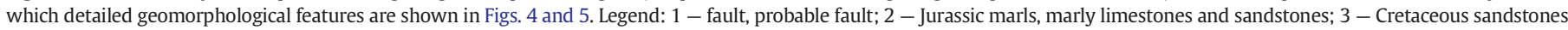

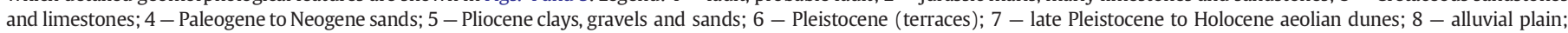
9 - beach. At northeast of the Serra da Boa Viagem structure, item 5 comprises undifferentiated Pliocene to Holocene sediments. 
to Figueira da Foz town (western central Portugal). It is a perennial fluvial system with a present average flow of $33 \mathrm{~m}^{3} / \mathrm{s}$ (1984-1994; C.C.D.R.C., 2000).

The first studies on the Quaternary sedimentary deposits of the Lower River Mondego were made by Ribeiro and Patrício (1943), Carvalho $(1949,1955)$ and Soares (1966). Based on the sedimentary characteristics, three groups of Pleistocene deposits were distinguished (Soares et al., 1989, 1993, 1997, 1998; Soares, 1999; Cunha and Almeida, 2008): an upper group of proximal fluvial deposits (Carqueija and Salabardos deposits) and, below an altitude of $60 \mathrm{~m}$, two groups of fluvial terrace deposits (Ameal-Santo Varão deposits and Tentúgal-Gabrielos deposits); however, this lithostratigraphy was established upstream of the present study area. Geomorphological research on the Lower River Mondego was undertaken by Almeida et al. (1990), Almeida (1997), Cunha and Soares (1997), Cunha et al. (1999), Ramos (2000, 2008), Cunha and Almeida (2008), Santos (2009) and Soares et al. (2010). In this region, the main active faults during the Quaternary were studied by Cabral and Ribeiro (1988), Cabral (1995) and Ribeiro et al. (1996).

Some difficulties arise in the correlation of terraces between adjacent reaches, or even on different sides of the river within a single reach of the same valley, because similar depositional facies can exist at different terrace levels and vertical displacements of the same surface can be produced by active tectonics. In this study we intend to describe the spatial and temporal distribution of the river terraces in the distal reach of the
Lower Mondego, despite some of the deposits being poorly developed and exposed in limited outcrops.

This paper focuses on the geomorphological and sedimentological characteristics of the Pleistocene river terrace staircase near the mouth of the Mondego, between Maiorca and Figueira da Foz (Fig. 1). Collectively, this work aims to contribute to an improved understanding of Pleistocene river development and its associated sedimentary and geomorphic controls. The three lower terraces comprise fluvial and marine facies (the latter in the SW, near the coastline), this co-existence being of critical importance for the interpretation of the driving mechanism of the terrace staircase, namely the role of sea-level in determining the sequence of terraces. The estimation of the uplift rates and the identification of probable active faults during the Quaternary are also important objectives.

\section{Geological setting}

\subsection{Regional lithologies}

In the middle and distal estuary sectors (Fig. 1), the River Mondego crosses: Lower to Upper Jurassic units, such as limestones, marly limestones and sandstones; Cretaceous limestones, claystones and sandstones; and Neogene sands and clays. Pleistocene and Holocene sedimentary units are represented by siliciclastic fluvial, colluvial, aeolian, estuarine and beach deposits.

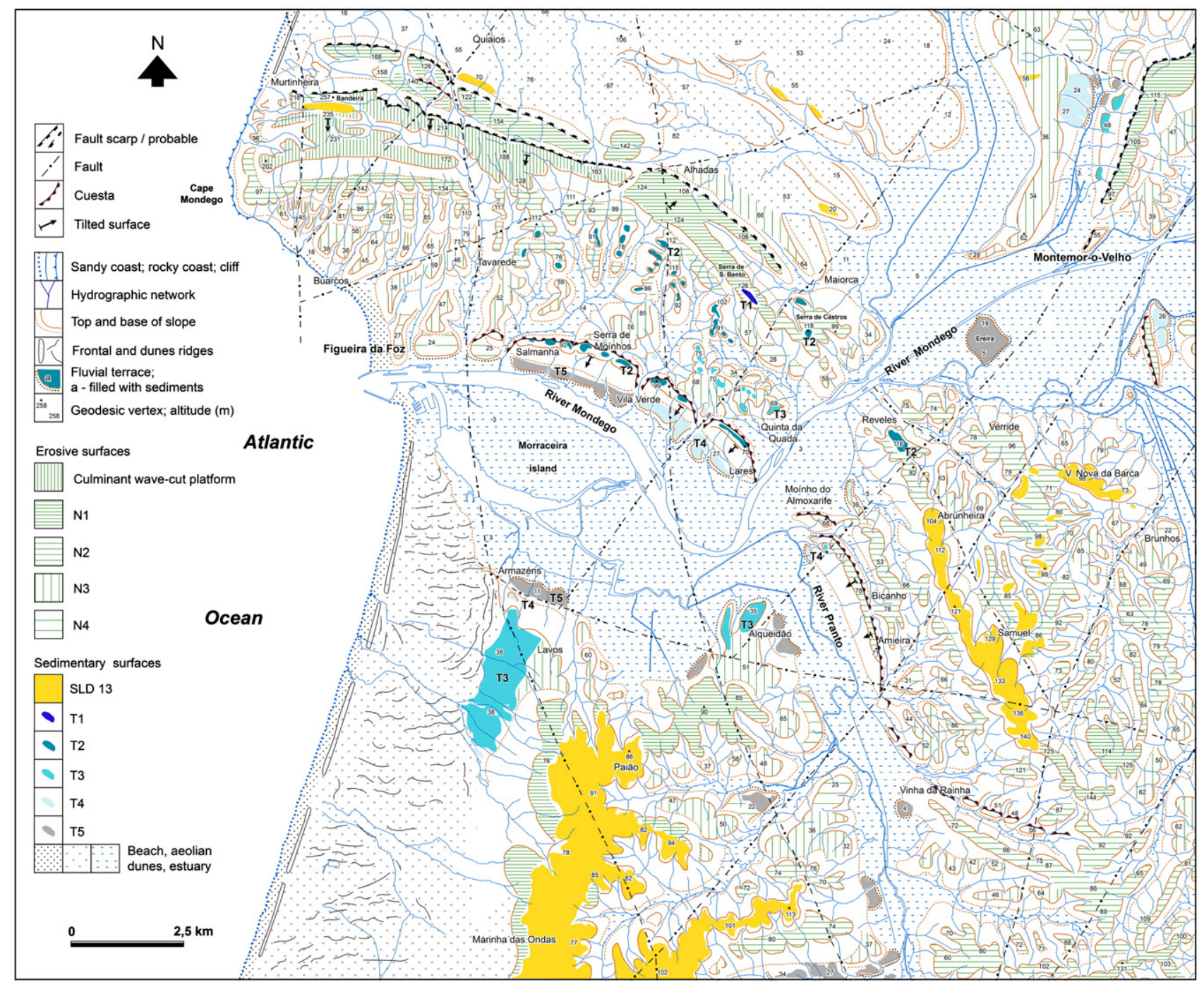

Fig. 2. Geomorphological map of the region. Updated from previous geomorphological maps (Almeida, 1997; Cunha and Soares, 1997; Soares et al., 1997; Ramos, 2000). 


\subsection{Tectonic structures}

The main tectonic structure of the region is a W-E to WNW-ESE trending arcuate thrust fault, verging to the north and northwest, named the Quiaios fault (Figs. 1-3; Cabral and Ribeiro, 1988; Cabral, 1995) whose trace in the field is not accurately known. It extends, probably from Ereira (eastern edge) to Murtinheira (western edge), next to Cape Mondego, extending offshore. This fault, which seems to control the northern flank of the Serra da Boa Viagem structure, is responsible for the overall uplift of this relief and its configuration into a monocline geometry, with slope angles decreasing progressively towards the southwest (Rocha et al., 1981). The Serra da Boa Viagem structure continues southeastward to the Verride anticline, forming a large sigmoidal geometry in plan view. Three NNW-SSE to N-S trending faults (named as Monte Real-Figueira da Foz, Carnide-Pranto and Arunca-Montemor-o-Velho) were identified in the Neotectonic Map of Portugal (Cabral and Ribeiro, 1988) as right-lateral strike-slip faults that were active during the Quaternary. There is also evidence of salt diapirism at Ereira (Ribeiro et al., 1979).

\section{Geomorphological setting}

The region shows a diversity of landforms that resulted from the action of marine, fluvial and aeolian processes, but also of lithologic and tectonic controls (Almeida, 1997; Ramos, 2000, 2008) (Fig. 2). The main landforms are described below.

\subsection{Structural forms}

The Serra da Boa Viagem is an E-W to WNW-ESE elongated and curved ridge (Fig. 2), consisting mainly of Jurassic limestones, with associated marls and sandstones, dipping towards SW to S. Its northern scarp face is the most impressive feature in the landscape (Almeida, 1997).

The higher part of the Serra da Boa Viagem structure (reaching $257 \mathrm{~m}$ a.s.l.) exposes a shore platform surface developed onto resistant Middle Jurassic limestones. In some places the platform surface possesses a cover unit of marine sands, whose base was dated biostratigraphically to 3.6 Ma (Zanclean-Piacenzian transition; Cachão, 1989; Cunha et al., 1993; Silva, 2001; Silva et al., 2010). The sands were stratigraphically defined as part of the Carnide Formation. This Formation forms part of the regional allostratigraphic unit SLD13 (sequence limited by regional sedimentary discontinuity; Cunha et al., 1993; Pais et al., 2012), of probable uppermost Zanclean to Gelasian age (Late Pliocene to Lower Pleistocene).

In the regional landscape there are other structural landforms, such as limestone ridges and cuestas on the southern flank of the Serra da Boa Viagem-Verride structure. These are particularly prominent between Lares and Salmanha (Figs. 2 and 4). Cuestas and limestone cliffs are cut by narrow streams forming watergaps with very steep slopes at right angles to the direction of the beds.

According to Almeida (1997), in the Serra da Boa Viagem structure the stream valleys are mainly controlled by bedrock lithology. On limestones and marls, broad open-shaped valleys dominate. On a sandy substratum, the valleys usually show transverse profiles characterized by a large upper reach, a convex and $\mathrm{V}$-shaped intermediate reach, and a flat and wide lower reach.

In the Lares gorge the River Mondego crosses the Serra da Boa Viagem-Verride structure (Figs. 1-3). It comprises two valley narrowings: one where the valley crosses Jurassic limestones and the other, owards the west, where the valley crosses Cretaceous limestones. The gorge is considered to be the combined result of superimposition (onto resistant limestone bedrock) and adaptation to a probable fault (Soares et al., 1989; Almeida et al., 1990; Ramos, 2000).

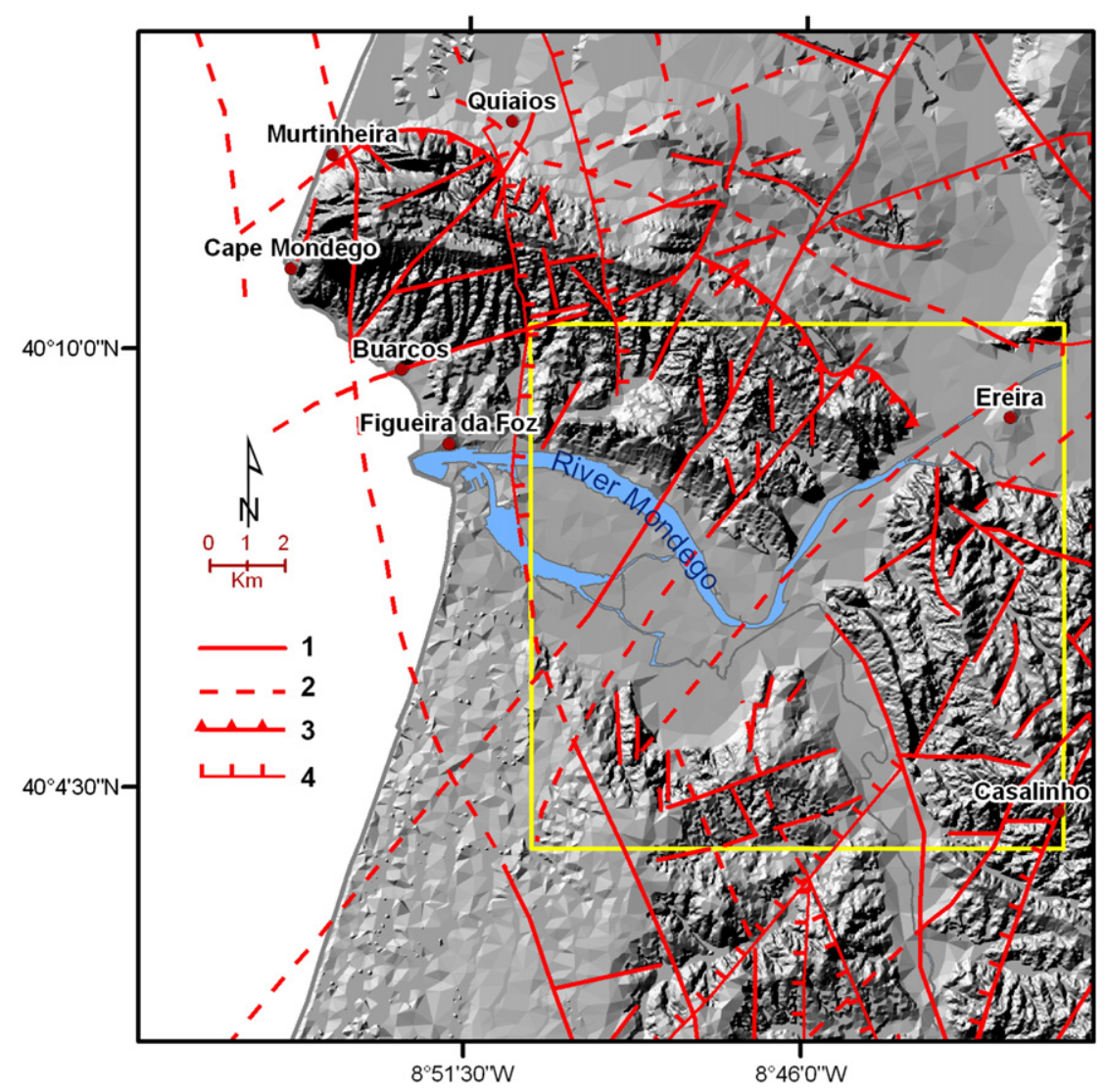

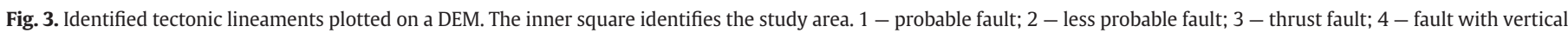
movement. 


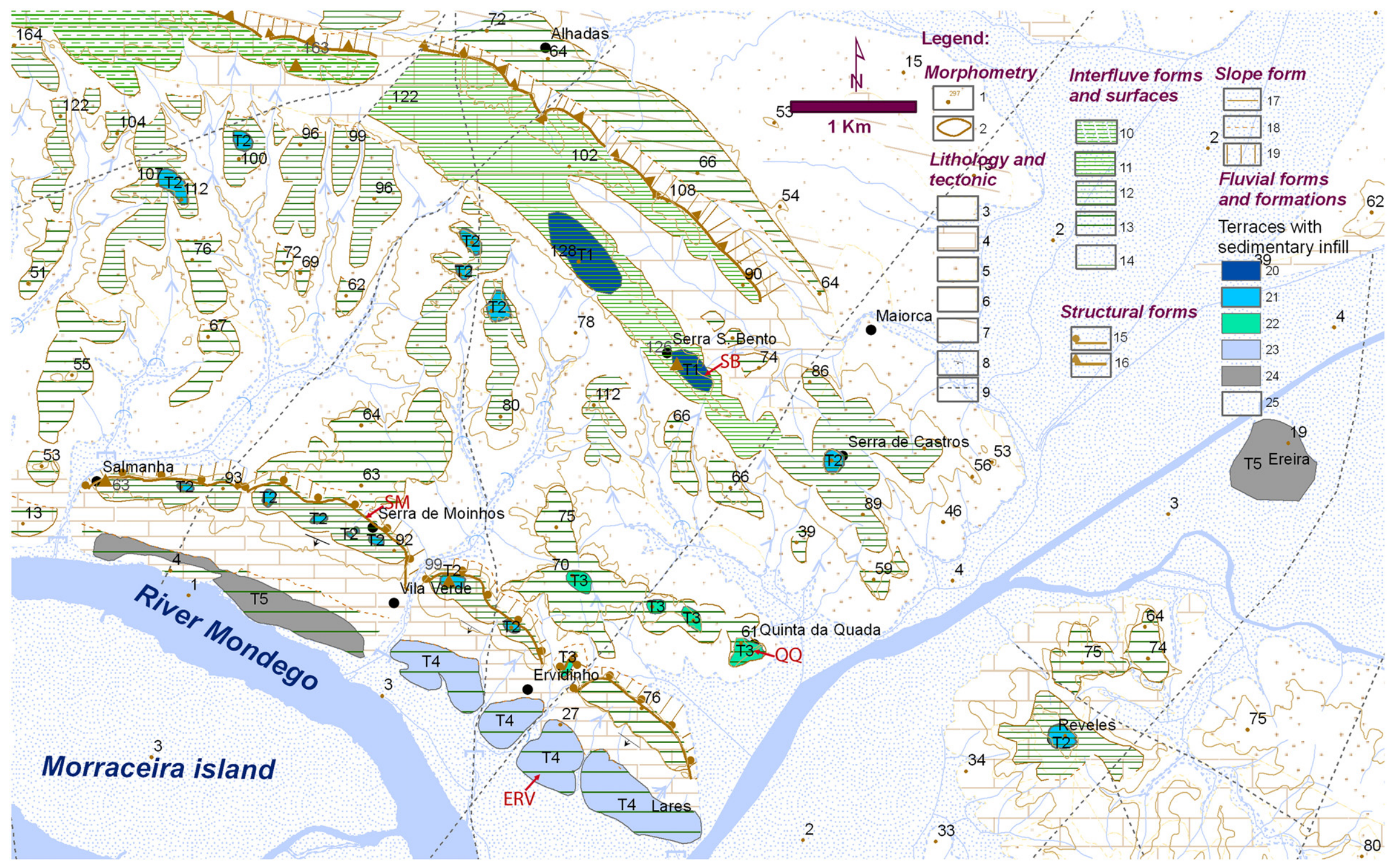

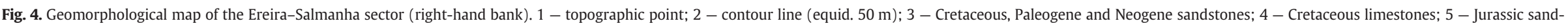

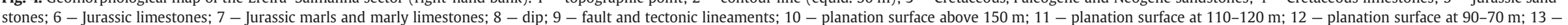

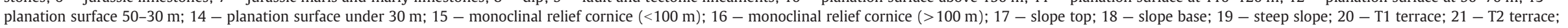
22 - T3 terrace; 23 - T4 terrace; 24 - T5 terrace; 25 - alluvial plain. Studied sites: ERV - Ervidinho; QQ - Quinta da Quada; SB - Serra de São Bento; SM - Serra de Moinhos. 


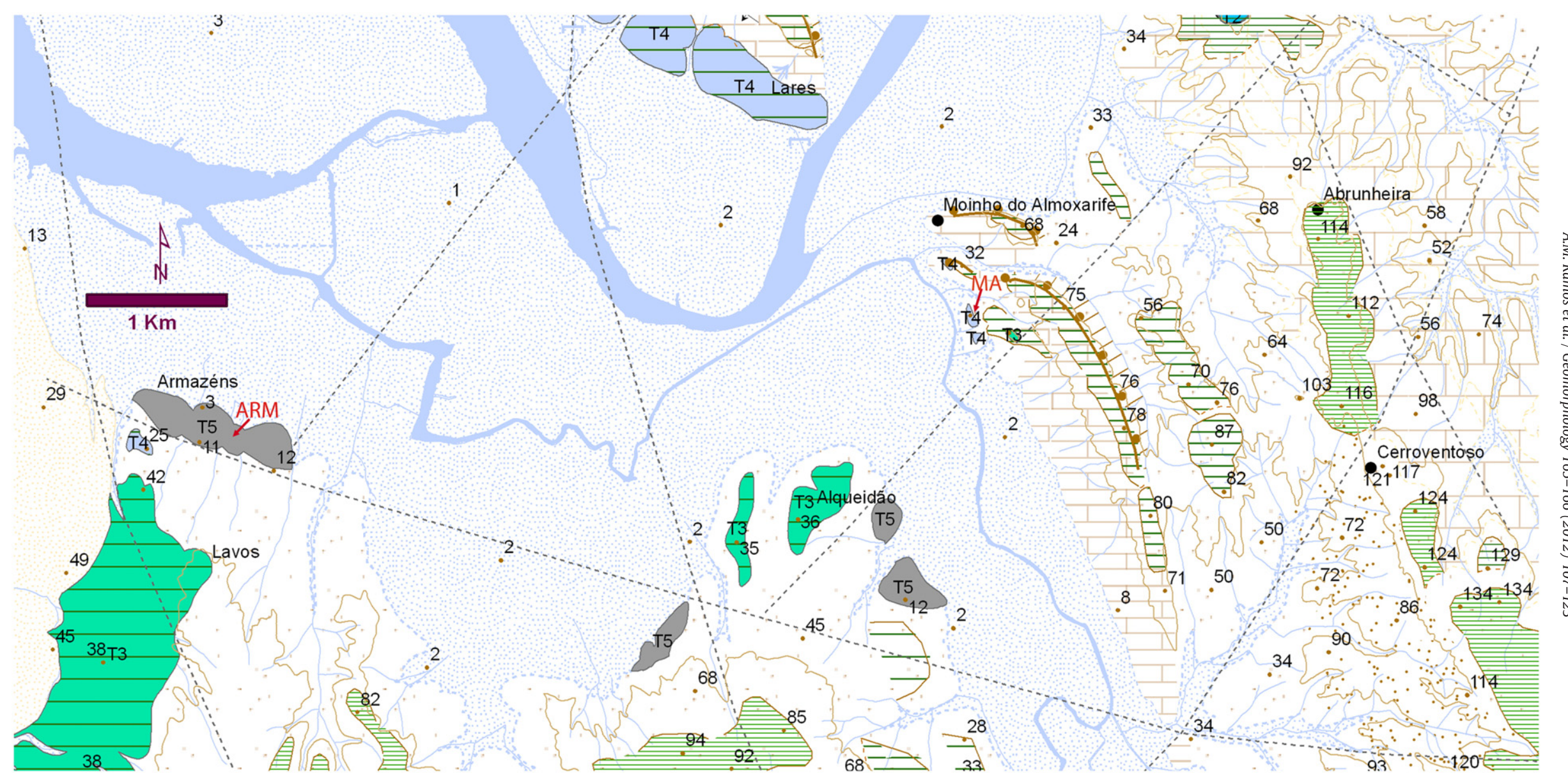

Fig. 5. Geomorphological map of the Abrunheira-Lavos sector (left-hand bank). The legend is the same of Fig. 4. Studied sites: ARM - Armazéns; MA - Moinho do Almoxarife. 
In the limestone areas, two episodes of karstification were recognized (Almeida, 2001): one is younger (Quaternary) and less evident, the other is older (probably of Cretaceous age) comprising well developed funnel-shaped dolines that reach $15 \mathrm{~m}$ in depth, although sometimes there are dish-shaped dolines, as well as swallow-holes and caves.

\subsection{Sedimentary landforms}

In the River Mondego Valley, the reach between Maiorca and Figueira da Foz (Figs. 1 and 2) has several terraces (T) that pass laterally into coeval planation surfaces $(\mathrm{N})$.

An alluvial plain is well developed along the Lower Mondego (Almeida et al., 1990; Cunha et al., 1997), becoming very narrow through the Lares gorge, as well as along tributaries. Holocene alluvium comprises fluvial gravelly sands that grade upward into estuarine sands and muds. Thicknesses vary from $32 \mathrm{~m}$ at Lares to $42 \mathrm{~m}$ at Morraceira Island (Rocha et al., 1981).

Significant colluvium, locally forming small alluvial fans with $2-4^{\circ}$ slopes, occurs mainly at the NW edge of the Serra de Boa Viagem (Almeida, 1997). The colluvium comprises angular limestone clasts in a clast-supported texture, probably related to the cold conditions of the Last Glacial Maximum.

The drainage network has developed at right angles to the direction of the monoclinal structure of the Serra da Boa Viagem, particularly on the southern slope. The Verride anticline is an intensely fractured fold structure (Figs. 2 and 3). Its hydrological network appears quite inappropriate with regard to the structure of the anticline, suggesting superimposition (Almeida, 1997). On limestone units, the streams tend to be fewer in number and show an orthogonal or rectangular drainage pattern, reflecting the typical regular fracture pattern found in limestone rocks. The drainage network developed in clays and sands (of Upper Jurassic, Cretaceous and Paleogene-Miocene age) shows a dense dendritic pattern (Almeida, 1997).

In the study area, the uppermost unit of the Mondego Cenozoic basin sedimentary infill (SLD13 in Fig. 2) comprises marine, yellowish, well sorted, micaceous sands, up to 15 to 10 m thick (Carnide Formation). Due to erosion, the basal surface is only locally exhumed; it is also displaced by tectonics (Cabral, 1995). In the study area, this Pliocene shore platform surface ranges from 220 to $257 \mathrm{~m}$ a.s.l. (near Bandeira, at the western sector of the Serra da Boa Viagem) to 140-150 m (west of Serra de S. Bento, at the eastern sector of the Serra da Boa Viagem) on the right-hand (northern) bank of the Mondego valley, but occurs at

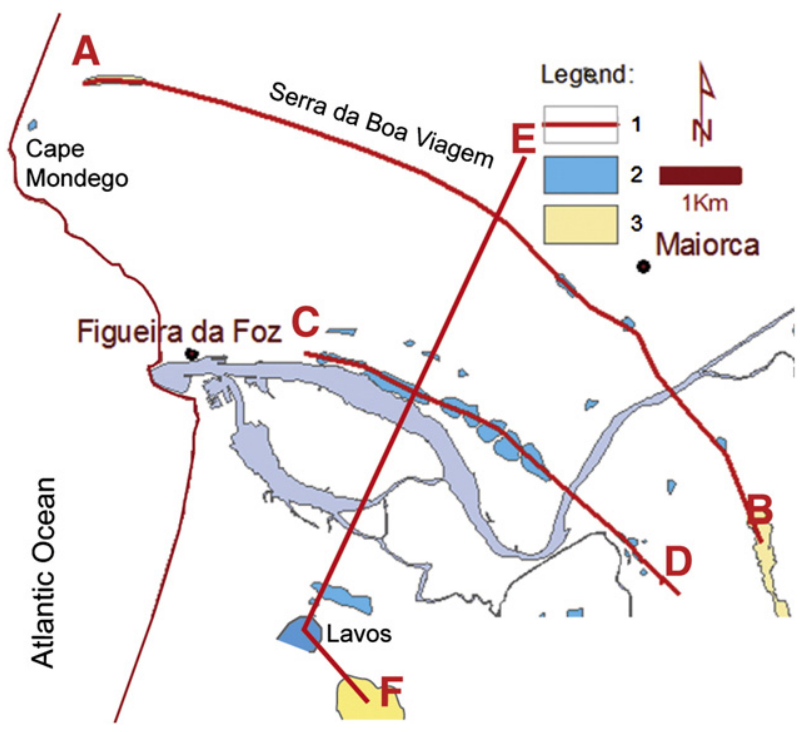

Fig. 6. Location of the transverse profiles in the River Mondego distal section. 1 - Track of a topographic profile; 2 - remains of a terrace; 3 - remains of the uppermost sedimentary unit (SLD13). lower altitudes on the left-hand bank (Abrunheira-Samuel, 100-125 m; Paião-Marinha das Ondas, 75-80 m a.s.l.) (Figs. 1 and 2).

At the Cape Mondego, a shore platform is preserved at 100 $\mathrm{m}$ a.s.l. near the lighthouse. The associated paleocliff is developed into limestone bedrock. Coarse marine beach sands and an overlying colluvium are developed onto the platform. The beach deposits include bioclasts of molluscs and crustaceans that indicate colder seawater conditions than those of today (Soares et al., 2007). At 2-8 $\mathrm{m}$ a.s.l. another shore platform is exposed at Murtinheira (Fig. 2). This platform is covered by a beach pebbly gravel and upper sand, $\sim 1 \mathrm{~m}$-thick and stratigraphically can be assigned to the last interglacial period (MIS5) due to its altitude (Soares et al., 1989, 1993; Cunha et al., 2005).

The coast at Cape Mondego consists entirely of cliffs. On its western side the cliffs have a convex profile, interrupted by the shore platform at $100 \mathrm{~m}$ a.s.l. The modern shore platform is associated with a coarse sandy beach.

Two aeolian dune fields, located north of the Serra da Boa Viagem (Carvalho, 1964; Noivo, 1996; Almeida, 1997; Danielsen, 2008) and south of the River Mondego (André, 1996; André et al., 2009) flank the study area.

\section{Methods}

Mapping of geomorphological features was undertaken in three stages: (1) field mapping onto topographical $(1 / 25,000)$ and geological $(1 / 50,000)$ base maps; (2) analysis of $1 / 26,000$ black/white aerial photographs and of a digital elevation model (DEM) based upon a $1 / 25,000$ topographic database, in order to improve the resolution of the field mapping and to produce valley longitudinal and transverse profiles; and (3) ground-truthing in the field to refine the geomorphological map produced from remote sensing. Terraces were correlated on the basis of their height above the modern channel (in the study area the river bed is at sea-level), with additional attention given to terrace surface gradients and continuity of their surfaces.

The tectonic features in the area were evaluated through the use of aerial photographs, DEM models and related hillshade models, constrained by field work. The identification of the main structural lineaments was done by visual interpretation.

Stratigraphic and sedimentological information was used to characterize the terrace deposits, namely the grain size, clast composition and lithofacies characterization using the Miall (1996) coding system.

Each sediment sample for Optically Stimulated Luminescence (OSL) dating was collected in a light-tight tube, together with some additional material in a waterproof plastic bag for later laboratory analysis of water content, grain size and mineralogical composition. OSL dating is a technique for measuring the time elapsed since sedimentary grains of quartz or feldspars were last exposed to daylight (Duller, 2004). The luminescence signal starts to accumulate in the mineral grains after burial due to ionizing radiation arising from the decay of ${ }^{238} \mathrm{U},{ }^{232} \mathrm{Th}$ and ${ }^{40} \mathrm{~K}$ present in the sediment. In the laboratory, the burial dose (expressed in Gy) is determined by comparing the natural luminescence signal resulting from charge trapped during burial with that trapped during a laboratory irradiation with a known dose. Dividing the burial dose by the environmental dose rate (expressed in $\mathrm{Gy} / \mathrm{ka}$ ) gives the luminescence age of the sediment. Environmental dose rates are calculated from the radionuclide concentrations of the sediment. In this study, the radionuclide concentrations were measured by high-resolution gamma spectrometry (Murray et al., 1987). These concentrations were then converted to environmental dose rates using the conversion factors given in Olley et al. (1996). For the calculation of the dose rate to sand-sized K-feldspar grains an internal $\mathrm{K}$ content of $12.5 \pm 0.5 \%$ was assumed (Huntley and Baril, 1997).

Because of the light sensitivity, the processing of sediment samples took place under subdued red light. Wet sieving was used to separate the $180-250 \mu \mathrm{m}$ grain size fraction, which was then treated using $\mathrm{HCl}$ (10\%) and $\mathrm{H}_{2} \mathrm{O}_{2}$ (10\%) to remove carbonates and organic matter, 
A

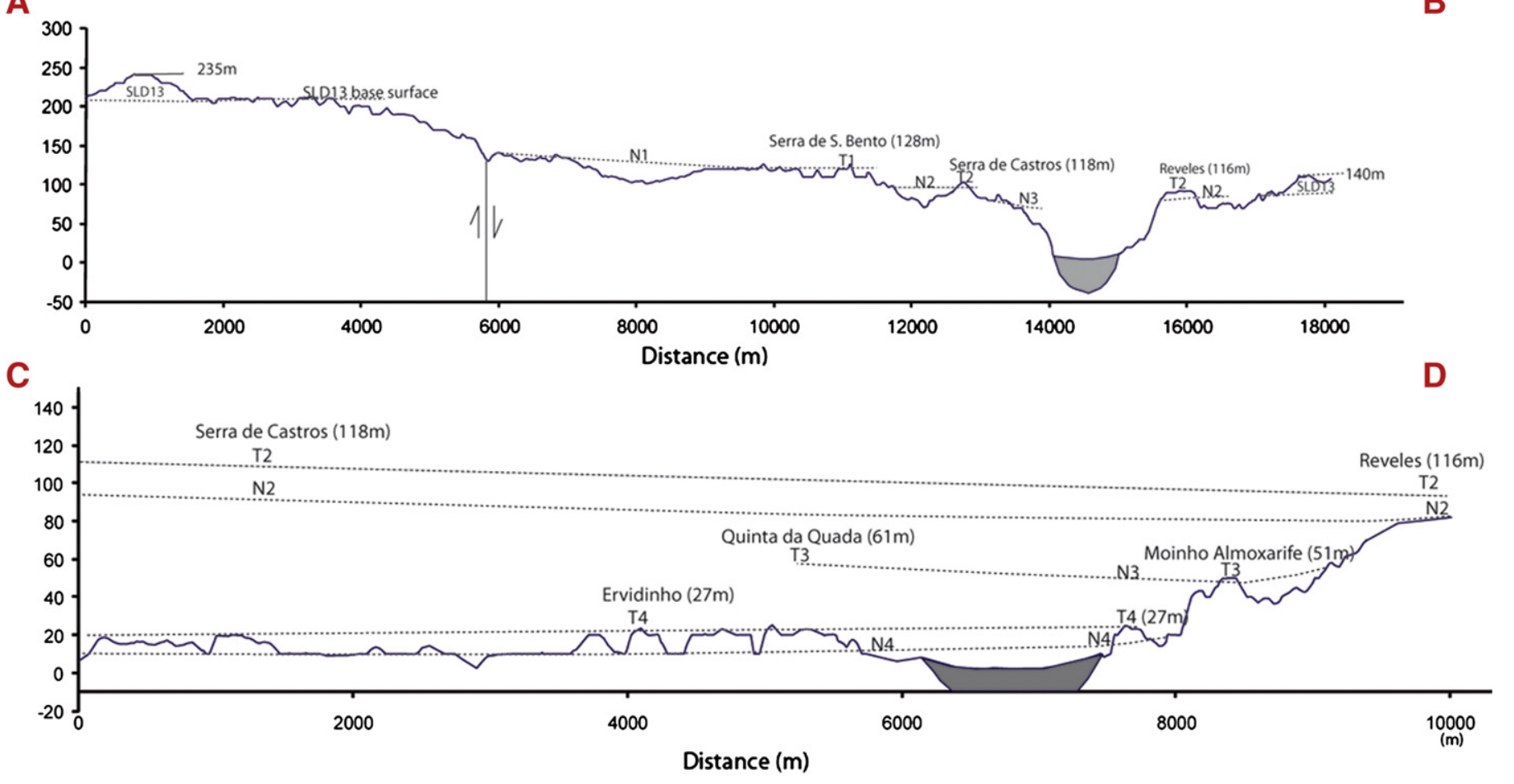

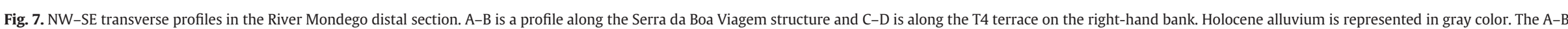
profile shows a probable vertical movement on the NNW-SSE trending Tavarede fault, displacing by $80 \mathrm{~m}$ the Pliocene shore platform surface (base of the SLD13 unit) that is at $\sim 220 \mathrm{~m}$ a.s.l. in the west and $\sim 140 \mathrm{~m}$ a.s.l. in the east. 
respectively. Using a heavy liquid solution of sodium polytungstate $\left(\rho=2.58 \mathrm{~g} / \mathrm{cm}^{3}\right)$ the K-feldspar fraction was floated off from a portion of the isolated $180-250 \mu \mathrm{m}$ fraction. The quartz fraction was obtained by etching another portion with concentrated HF (40\%). The K-feldspar fraction was treated with $10 \%$ HF for 40 min to remove the outer alphairradiated layer and to clean the grains. After etching, both the quartz and K-feldspar fractions were treated with $\mathrm{HCl}(10 \%)$ to dissolve any remaining fluorides.

Measurements of the equivalent doses $\left(D_{e}\right)$ were performed on automated Risø TL/OSL DA-15 readers calibrated for stainless steel disks and cups (Bøtter-Jensen et al., 2003). Quartz measurements were made on large $(8 \mathrm{~mm})$ aliquots containing several thousands of grains mounted on stainless steel disks. Small $(2 \mathrm{~mm})$ aliquots of K-feldspar were mounted on stainless steel cups.

Generally, the major drawback of the most light-sensitive part of the quartz OSL signal is that it saturates at $<200 \mathrm{~Gy}$, limiting the age range to $<150 \mathrm{ka}$ (Thomsen et al., 2011). In the study area, because of the relatively high dose rates $(1.3-5.2 \mathrm{~Gy} / \mathrm{ka})$, quartz luminescence was only suitable to date one sample. As a result, we decided to work also with density-separated K-rich feldspar grains (180-250 $\mu \mathrm{m})$.

Quartz dose estimates used a standard UV SAR protocol with a $240{ }^{\circ} \mathrm{C}$ preheat for $10 \mathrm{~s}$, a $200{ }^{\circ} \mathrm{C}$ cut heat, and blue stimulation at $125^{\circ} \mathrm{C}$ (Murray and Wintle, 2003). The extracted quartz was pure, as indicated by the absence of infrared stimulated luminescence; the OSL signal is dominated by a fast component.

The K-feldspar $\mathrm{D}_{\mathrm{e}}$ values were measured using a post-IR IRSL SAR protocol (Buylaert et al., 2012). After a preheat of $320^{\circ} \mathrm{C}$ for $60 \mathrm{~s}$ the aliquots are first IR bleached at $50{ }^{\circ} \mathrm{C}$ for $200 \mathrm{~s}$ and subsequently stimulated again with IR-light at $290^{\circ} \mathrm{C}$ for $200 \mathrm{~s}$. It has been shown by Buylaert et al. (2012) that the post-IR IRSL signal measured at $290{ }^{\circ} \mathrm{C}$ gives accurate results without the need to correct for signal instability. For all calculations the initial $2 \mathrm{~s}$ of the luminescence decay curve minus a background derived from the last $50 \mathrm{~s}$ was used.

\section{Geomorphological and sedimentary characteristics of the terrace staircases}

Above the modern floodplain ( $2 \mathrm{~m}$ a.s.l.), five terraces (numbered T1 [highest] to T5 [lowest]) were identified (Figs. 4-8; Table 1). In some places it was difficult to distinguish the terrace deposits from the underlying Mesozoic substratum due to similarities in lithologies. This is especially the case for the higher and older terraces, which are generally less well exposed.
Table 1

Altitudes of the culminant unit of the sedimentary infill (SLD13) and other surfaces, at the River Mondego estuary.

\begin{tabular}{|c|c|c|}
\hline Geomorphic reference & $\begin{array}{l}\text { Left river bank } \\
\text { (Lavos-Alqueidão sector) }\end{array}$ & $\begin{array}{l}\text { Right river bank } \\
\text { (Maiorca-Vila Verde sector) }\end{array}$ \\
\hline SLD13 surface & $110 \mathrm{~m}$ & $? \sim 160 \mathrm{~m}$ (eroded) \\
\hline T1 (Serra de São Bento) & Almost not represented & $\begin{array}{l}125-128 \mathrm{~m} \\
\text { (aggradation surface) }\end{array}$ \\
\hline T2 (Serra de Moinhos) & Not represented & $\begin{array}{l}\text { 90-101 m } \\
\text { (aggradation surface) }\end{array}$ \\
\hline T3 (Quinta da Quada) & $\begin{array}{l}35-42 \mathrm{~m} \\
\text { (aggradation surface) }\end{array}$ & $\begin{array}{l}\text { 60-64 m } \\
\text { (aggradation surface) }\end{array}$ \\
\hline T4 (Ervidinho) & $\begin{array}{l}25 \mathrm{~m} \\
\text { (aggradation surface) }\end{array}$ & $\begin{array}{l}24-29 \mathrm{~m} \\
\text { (aggradation surface) }\end{array}$ \\
\hline T5 (Armazéns) & $\begin{array}{l}8-10 \mathrm{~m} \\
\text { (aggradation surface) }\end{array}$ & $\begin{array}{l}\text { 10-11 m } \\
\text { (poorly represented) }\end{array}$ \\
\hline Alluvial plain & $2 \mathrm{~m}$ & $2 \mathrm{~m}$ \\
\hline Modern river bed & $0 \mathrm{~m}$ & $0 \mathrm{~m}$ \\
\hline
\end{tabular}

On the left-hand bank of the River Mondego, the T1 terrace, named Serra de São Bento Terrace, is only represented locally as an erosion surface. On the right-hand bank, the T1 terrace comprises 2 m-thick deposits with a terrace surface between 125 and $128 \mathrm{~m}$ a.s.l. (Table 1). At the Serra de São Bento outcrop (Fig. 9), the T1 sediments consists of a matrix-supported to clast-supported, poorly to moderately sorted gravel that infills channel forms (a local channel axis has a N240 direction) with planar cross-stratification and clast imbrication. The clasts reach $14 \mathrm{~cm}$ (Mean Particle Size [MPS] $=12 \mathrm{~cm}$, average of the largest 10 clasts) and are characterized by quartzite (50\%), quartz (45\%), and several other subordinate lithologies of sandstone and highly weathered phyllites. Clasts are rounded to angular and show a yellow iron-stained patina. At the base of the terrace deposits it is possible to identify clasts reworked directly from the underlying strata (e.g. Jurassic).

The T2 terrace, named the Serra de Moinhos Terrace, occurs at 90-101 m a.s.l. on the right-hand bank (e.g. Salmanha and Serra de Castros sites). It consists of 2 to $6 \mathrm{~m}$ thick matrix-supported gravels, showing horizontal stratification, planar cross-stratification and clast imbrication (Figs. 10 and 11). The clasts are characterized by quartzite and quartz, have a MPS $=8 \mathrm{~cm}$, are poorly sorted, angular to subrounded and have a red-stained patina. The sandy-silty matrix is dominated by medium sand (modal grain size $\sim 1.5 \varnothing$ ) and consists mainly of quartz, K-feldspar, Na-rich plagioclases and clay minerals (kaolinite - 70\% and illite - 30\%). At Serra de Moinhos, the terrace deposits and the underlying Cretaceous beds are affected by faults with a $\mathrm{N} 70^{\circ} \mathrm{W}$, $60^{\circ} \mathrm{SW}$ attitude (Fig. 10). The T2 deposits can also be found at the

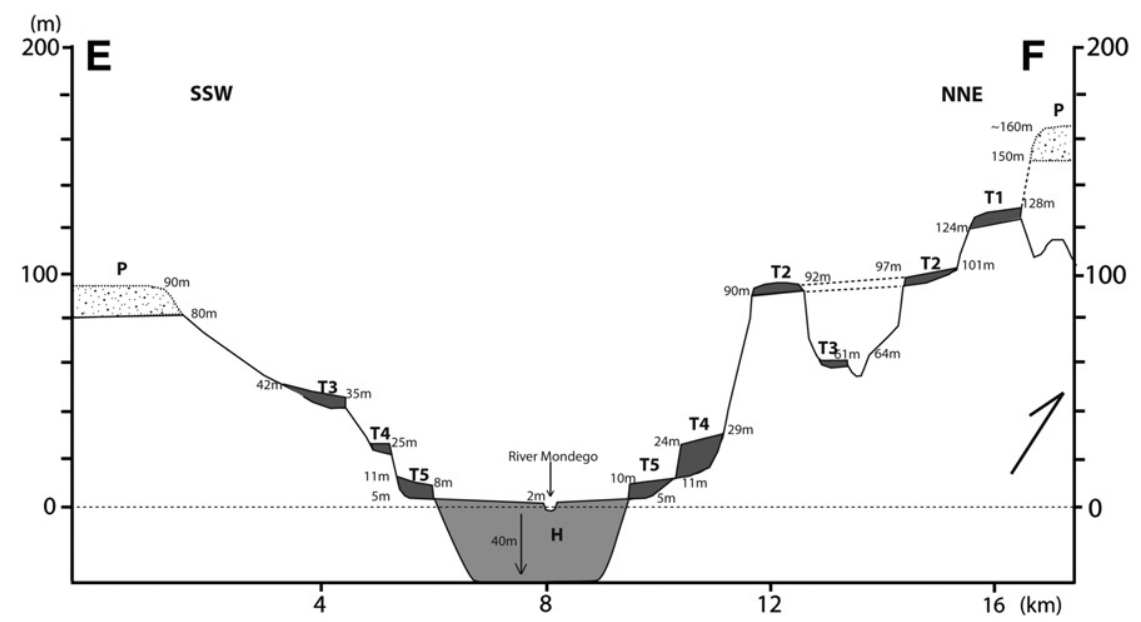

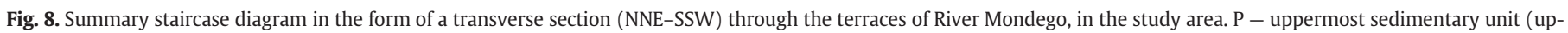
permost Zanclean to Lower Pleistocene); T1 to T5 - terraces (Pleistocene); H - alluvial infill (uppermost Pleistocene and Holocene). 


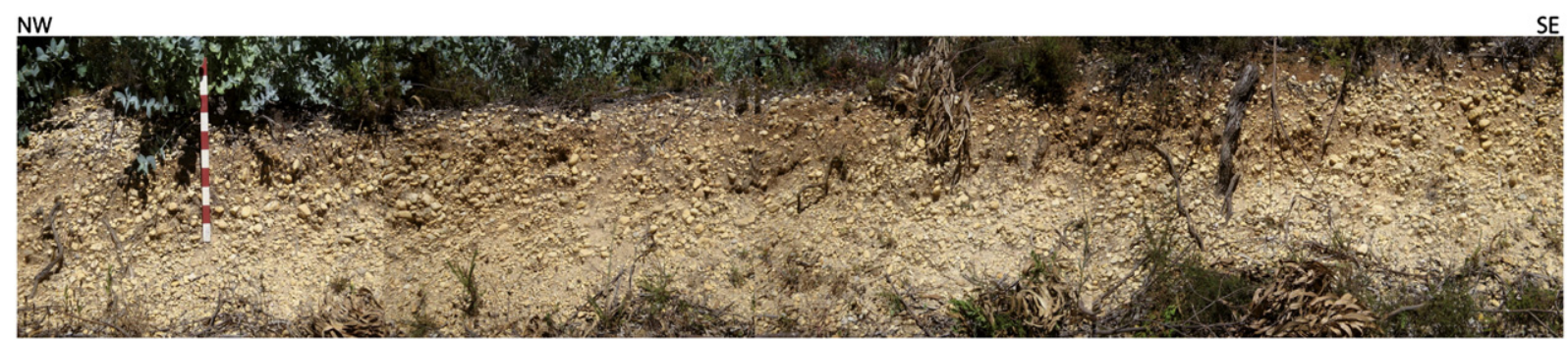

Fig. 9. Outcrop exposing the fluvial gravels of the S. Bento terrace (T1). The rule is $1 \mathrm{~m}$ long.

same altitude in the Salmanha cuesta, infilling karst forms. On the lefthand bank, the preserved maximum thickness is less than $1 \mathrm{~m}$.

The T3 terrace, called the Quinta da Quada Terrace, has its surface at 75-60 $\mathrm{m}$ a.s.l. on the right-hand bank (Quinta da Quada). The terrace is $<6 \mathrm{~m}$ thick and consists of gravels composed of well-rounded to angular clasts of quartzite and quartz, with a MPS $=35 \mathrm{~cm}$ (Fig. 12). On the lefthand bank, the T3 is represented at Alqueidão (surface at $36 \mathrm{~m}$ a.s.l., comprising fluvial sands) and Lavos (at 38-35 m a.s.l., comprising pebbly beach sands, interpreted on the basis of well-rounded quartzite and quartz clasts with a good sorting) (Fig. 5).

Terrace T4, named the Ervidinho Terrace, is represented on the right-hand bank between Lares and Vila Verde by fluvial facies, at 29-24 m a.s.l. The Ervidinho outcrop shows that the T4 terrace overlies Cretaceous bedrock, is $11 \mathrm{~m}$ thick and comprises following sequence (from base to top; Figs. 13 and 14):

$3 \mathrm{~m}$ - brown to yellow clast-supported fluvial gravels, with planar and trough cross-stratification and clast imbrication, composed of moderately sorted well-rounded to angular clasts of quartzite (60\%), quartz (30\%) and phylites (10\%), MPS $=30 \mathrm{~cm}$. In this and the T3 terrace, some well-sorted and very well-rounded white quartz elements also occur (MPS $=3 \mathrm{~cm}$ ).

$6.2 \mathrm{~m}$ - yellow to white, well to moderately-sorted, fine sands (modal grain size $\sim 1.35 \varnothing$ ), with horizontal lamination, followed by moderately to poorly-sorted medium to coarse yellow sands (modal grain size $\sim 0.14 \varnothing$ ) with thin intercalations of gravels (moderately-rounded to angular clasts); the surface characteristic of the quartz sand grains indicate a probable mixture of fluvial and aeolian processes. The sediments show ripple marks, planar crossstratification and bimodal paleocurrents interpreted as an intertidal environment.

$2 \mathrm{~m}$ - Gray silty-sands (modal grain size $\sim 1.8 \varnothing$ ), moderately sorted, with horizontal lamination interpreted as fluvial overbank fines.

These sands and silts are mineralogically composed of quartz, Kfeldspar, Na-rich plagioclases and clay minerals (kaolinite $-70 \%$, illite - 30\%, and rare mixed-layer minerals $10-14 \mathrm{M}$ ). On the left-hand bank, T4 is represented at $25 \mathrm{~m}$ a.s.l. at a site located between Lavos and Armazéns. Here, despite poor exposure, the facies are interpreted as sandy beach gravels on the basis of well-rounded quartzite and quartz clasts with a good sorting.

Terrace T5, named the Armazéns Terrace, has a surface at 10-8 m a.s.l., is $3 \mathrm{~m}$ thick and is mainly preserved on the left-hand bank. The best outcrop is located at Armazéns, where it comprises: a $0.4 \mathrm{~m}$-thick basal layer of well-rounded beach gravels overlain by a $\sim 2.8 \mathrm{~m}$ thick layer of white medium to fine sands interpreted as an intertidal bar subenvironment within an estuarine setting (Fig. 15). On the right-hand bank, this terrace is mainly represented by a strath at $10-11 \mathrm{~m}$ a.s.l. Locally, T5 outcrops reveal a gravelly base, followed by sands and a coal-rich clay at the top. Further upstream, this terrace is probably represented at Ereira where it consists of sandy gravels and is tilted to the south (surface altitude changing from 19 to $5 \mathrm{~m}$ ), probably resulting from local diapirism promoted by Lower Jurassic evaporites and marls.

In the study area, as above described, the upper terraces (T1 and T2) only display coarse-grained fluvial facies. These comprise clast and matrix-supported reddish gravels; angular to rounded clasts; poorly to moderately sorting; showing some channel geometries, planar and trough cross-stratification, and clast imbrication. Usually, each terrace comprises fluvial facies that are overlain by colluvium. However, the younger terraces (T3, T4 and T5) document spatial changes between distal fluvial deposits (well organized and moderately sorted gravels, sands and clays; located more upstream) and coastal deposits (intertidal and beach facies; located near the present coastline), in a very similar disposition to that of the modern sedimentation of this coastal area. The identification of intertidal and shallow marine facies on the three lower terraces, located at $2 \mathrm{~km}$ inland of the present coastline, indicates that during their periods of valley aggradation by coastal sediments, the coeval sea level was above the present level. The proximity to the paleocoastline suggests that an important control on terrace genesis was probably that of glacio-eustacy.

\section{Tectonic analysis of the relief}

As previously noted, the main tectonic feature of the study area is the W-E to WNW-ESE trending Serra da Boa Viagem-Verride complex structure bounded to the north by the Quiaios fault (Fig. 1). The fault trace represented on the $1 / 50,000$ geological map and drawn between Montemor-o-Velho and NW of Alhadas has no associated scarp (Figs. 2

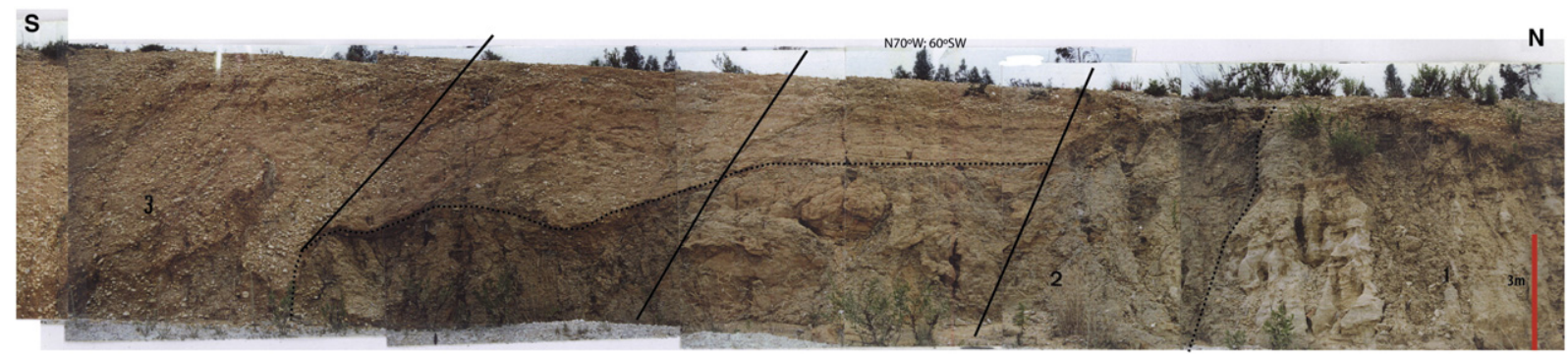

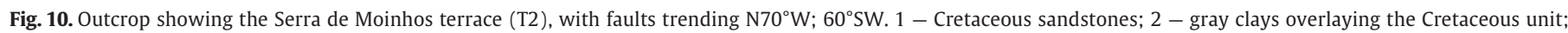
3 - matrix-supported gravels. 


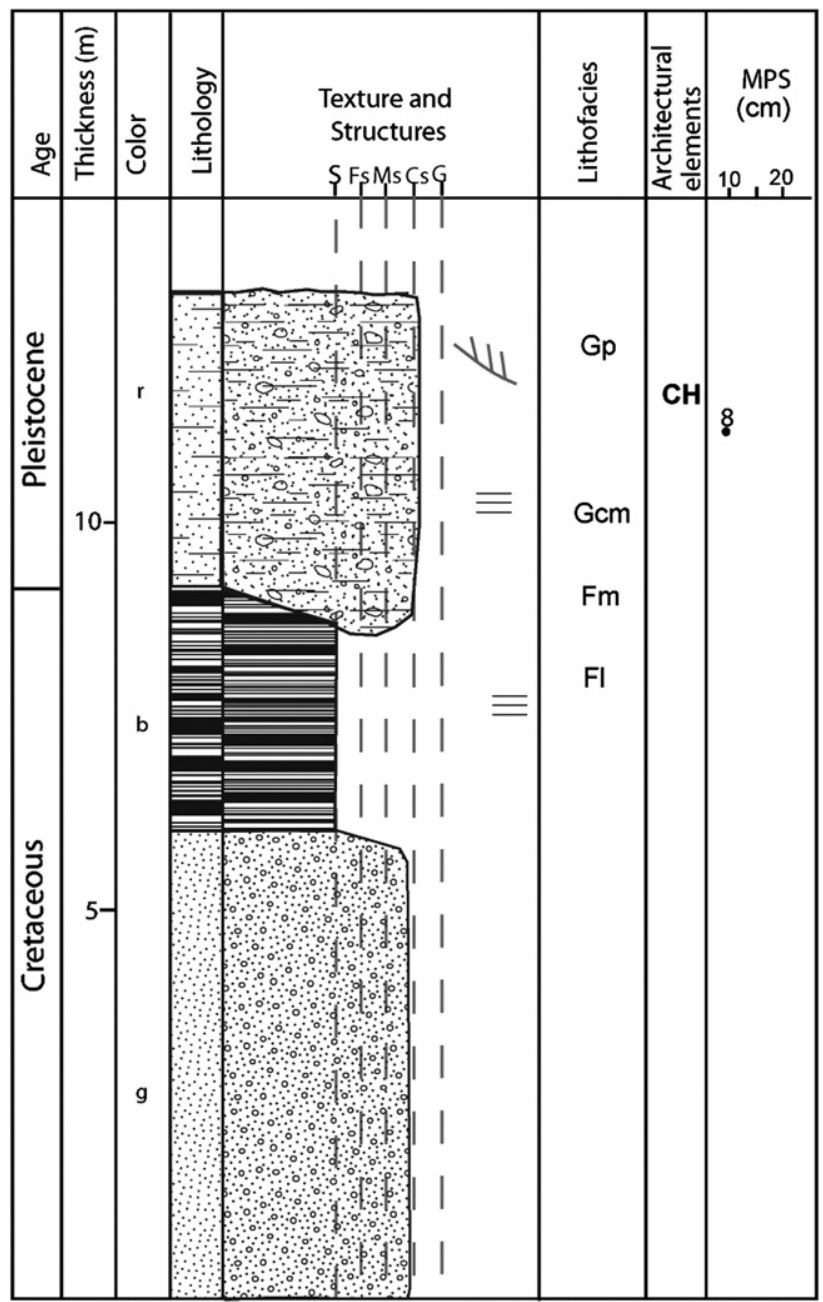

Fig. 11. Stratigraphic column made on a deposit of the Serra de Moinhos terrace (T2). $\mathrm{Gp}$ - gravel, stratified with planar cross-beds; Gcm - clast-supported massive gravel; Fm - massive silt.

and 3). However, the evident tectonic scarp passes through Maiorca, Alhadas and south of Quiaios roughly parallel to the main fault trace. In our opinion this is the fault that has been active during the Quaternary. The Quiaios fault seems to comprise an imbricate thrust complex, expressed at the surface as a succession of fault bounded thrust slices,

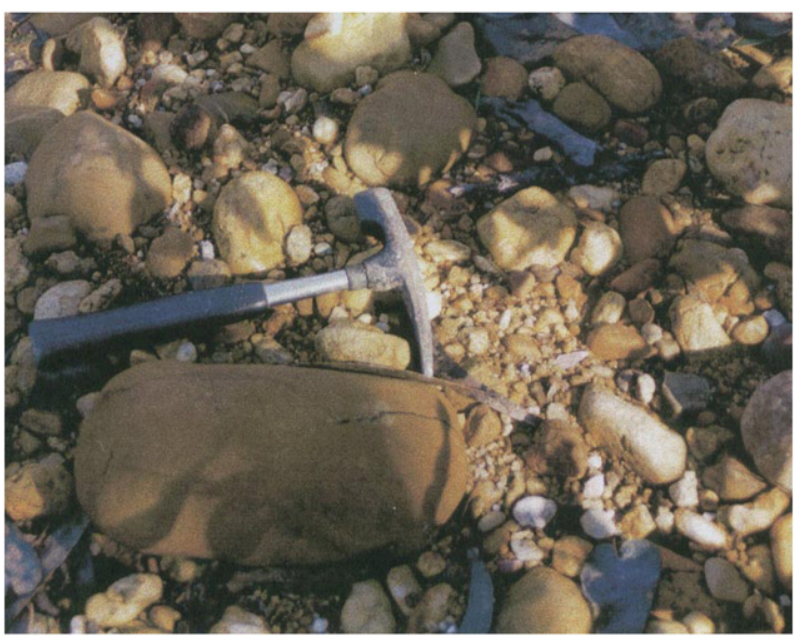

Fig. 12. Fluvial boulder and cobble gravels of the Quinta da Quada terrace (T3). as suggested by the geometries of the associated fault and their position related to the main thrust plane.

At an abandoned sand pit located at $122 \mathrm{~m}$ a.s.l., south of Quiaios, Lower Jurassic limestones have been thrust above a marine sandy unit ascribed as "Quaternary" by Carvalho (1952) and Barbosa et al. (1988). The sandy unit disconformably overlies Cretaceous sandstones. However, based on the similarity of facies, we consider this yellowish marine sandy unit as equivalent to that capping the Serra da Boa Viagem structure (1 km south of Bandeira, top at $235 \mathrm{~m}$ and base at $220 \mathrm{~m}$ a.s.l.), representing marine sands of the SLD13 unit, on the uplifted block of the Quiaios fault (a vertical displacement of $118 \mathrm{~m}$, but reaching $135 \mathrm{~m}$ at Bandeira). Also, taking into account the position of the Pliocene shore platform surface at $20 \mathrm{~m}$ a.s.l. just north of Maiorca and at $\sim 150 \mathrm{~m}$ of altitude to the west of S. Bento, it seems that a WNW-ESE trending fault along Quiaios-AlhadasMaiorca could also explain this vertical displacement (130 m) (Figs. 2 and 3).

The analysis of aerial photography, DEM and related hillshade models, complemented with field data also suggests several probable tectonic lineaments, representing two main systems:

- a NNW-SSE trending system defining a tectonic corridor $\sim 30 \mathrm{~km}$ wide, with inflected segments and vertically displaced compartments that seem to be more uplifted towards the WNW leading to the elevation of Cape Mondego $(\sim 120 \mathrm{~m}$, due to the different altitudes of the Pliocene shore platform surface reaching $257 \mathrm{~m}$ at Bandeira and $140 \mathrm{~m}$ west of S. Bento). Some probable left-lateral strike-slip movement could also be present, taking into account the assumed WNW-ESE maximum horizontal compressive stress (Ribeiro et al., 1996; Bezzeghoud et al., 2000; De Vicente et al., 2011). An example of these alignments is the Tavarede fault, located in the westernmost sector of the Serra da Boa Viagem structure (Fig. 3).

- a NE-SW trending system, with more elevated sections towards to the Sicó Massif and Estremenho Massif (in the southeast). A thrusting component is expected. However, some probable rightlateral strike-slip movement could also be represented, taking into account the assumed WNW-ESE maximum horizontal compressive stress.

In the Vila Verde-Maiorca sector and in the Lavos-Abrunheira sector, the terrace remains (deposits or erosion surfaces) do not show clear topographic evidence of vertical tectonic displacements. The same applies to the Lares gorge, where no vertical movement can be deduced when comparing similar geomorphic markers on both sides of the gorge (Fig. 7; only a regional southwards tilting). However, at some sites the terraces are affected by tectonics. For example, at Serra de Moinhos, the T2 terrace is displaced by $N 70^{\circ} \mathrm{W}, 60^{\circ} \mathrm{SW}$ oriented faults (Fig. 4 and 10).

\section{Luminescence dating}

For luminescence dating, several sediment samples were collected: (i) three samples, respectively, from the base (code 052245), middle (code 062227) and top (code 052234) of the T4 terrace deposits (at the Ervidinho site; Figs. 4, 13, and 14); (ii) one colluvium sample (code 052256) from a local deposit tentatively related to T4 at Moinho do Almoxarife (Fig. 5); (iii) three samples, respectively, from the base (code PC5224), middle (052259) and top (code PC5218) of the T5 terrace deposits (at the Armazéns site; Figs. 5 and 15).

The results of the luminescence dating are presented in Tables 2, 3 and 4. We first discuss the results of the oldest deposits (T4). For the T4 samples (062227, 052245 and 052234 ) optically stimulated luminescence dating using quartz was not attempted because we were confident that they would be beyond the applicable age range. PostIR IRSL dating of K-rich feldspar extracts gave natural luminescence signals well beyond the level usually accepted as indicating saturation 
A
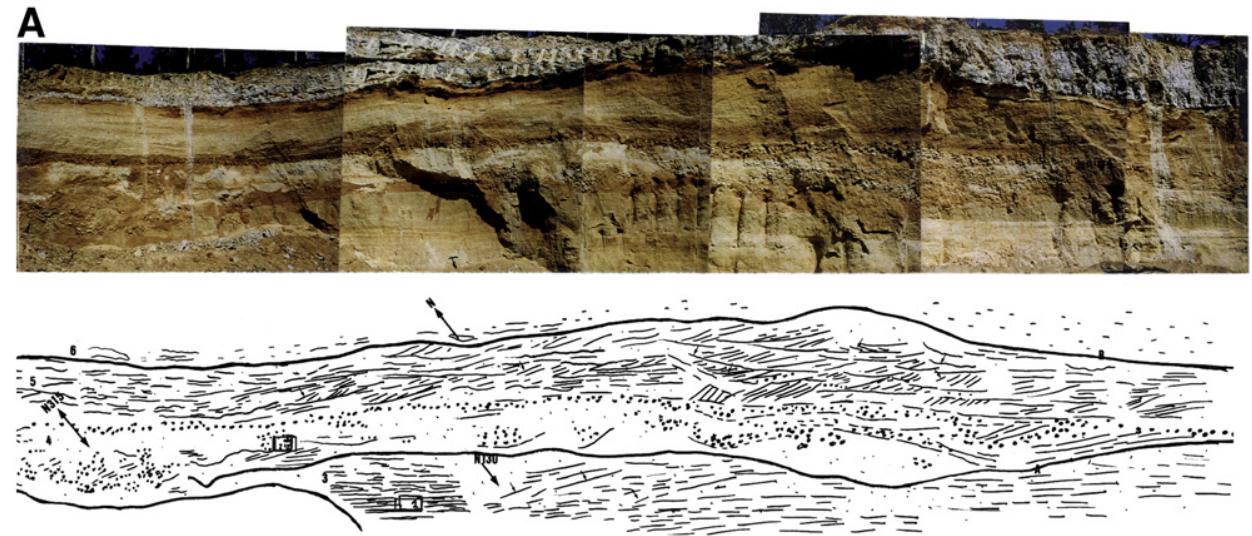

B

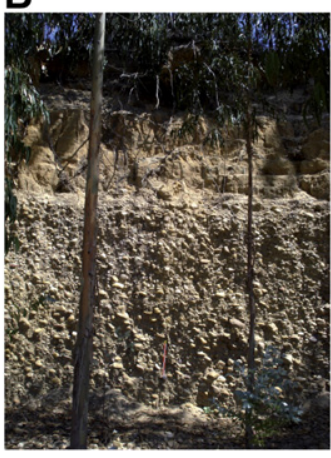

Fig. 13. Outcrop exposing the Ervidinho terrace (photo and draw), comprising fluvial gravels at the base overlain by fluvial and intertidal sands and clays.

( $\sim 86 \%$ of the saturated pIRIR 290 signal). From the shape of the dose response curves this corresponds to a dose of $\sim 1000 \mathrm{~Gy}$. So, the resulting ages need to be considered as minimum estimates, respectively, of $>340 \mathrm{ka}$ (base, 052245), > $390 \mathrm{ka}$ (middle, 062227) and >170 ka (top, 052234) (Table 4).

Sample 052256, collected from colluvium at $35 \mathrm{~m}$ a.s.l. and located near Moinho do Almoxarife, has a pIRIR 290 age of only $53 \pm 3 \mathrm{ka}$ (Table 4) and is clearly not chronologically associated with the T4 genesis. The OSL quartz signal for this sample (052256) is considered to be in saturation ( $>60 \mathrm{ka}$ ).

Samples from the base (code PC5224), middle (052259) and top (code PC5218) of the T5 terrace deposits (at the Armazéns site; Figs. 5 and 15) have been dated using both quartz and feldspar. The natural quartz OSL signal of all samples (Table 3 ) lies close to the upper 2D0 limit suggested by Wintle and Murray (2006) as considered practical for dating the upper age limit of quartz OSL (e.g. the ratio of natural to saturation level for sample 052259 is $0.85 \pm 0.02$, $\mathrm{n}=12$ ). As a result, the quartz $\mathrm{D}_{\mathrm{e}}$ for these samples should be treated with caution. The dose recovery test (Murray, 1996) was satisfactory (Table 3). The natural doses for these samples are similar to the doses measured in the studies of Murray and Funder (2003) and Murray et al. (2007); they found possible underestimation at $130 \mathrm{ka}$ of about $10-15 \%$. The resulting average quartz OSL age for the three samples is $111 \pm 8 \mathrm{ka}$. This quartz OSL date can be tested against the corresponding pIRIR ${ }_{290}$ feldspar result. In this case the feldspar natural signal is only $\sim 40 \%$ of saturation and so the above reservations do not apply to the average feldspar age of $108 \pm 5 \mathrm{ka}$ (Table 4 ). We conclude that the medium to fine sands of proposed intertidal origin collected in T5 at Armazéns (Mondego left-hand bank) were deposited at $109 \pm 4 \mathrm{ka}$.

\section{Discussion}

Five Pleistocene terraces were identified in the area of the Mondego lower estuary ( $\mathrm{T} 1$ to $\mathrm{T} 5$ ), all located below the uppermost sedimentary unit in the basin fill (SLD13; Upper Pliocene to Lowermost Pleistocene) and above the modern alluvial plain.

Paleogeographic reconstruction of each geomorphic level identified in the study area is presented in Fig. 16, documenting the transverse drainage of the River Mondego on the Lares gorge and the different phases of terrace formation. For the younger terraces (T5, T4 and T3), the paleogeographic reconstructions show a very similar disposition to that of the modern sedimentation of this coastal area, documenting the transition from fluvial to beach environments and leading to the interpretation of a coeval sea-level more elevated than the modern one.

Terraces $\mathrm{T} 1$ and $\mathrm{T} 2$ can be distinguished from the T3, T4 and T5 by their higher topographic position and their sedimentary facies (less organized, higher matrix content, but also clasts with lower maximum size and less rounding). So, the periods of aggradation represented by the T1 and T2 deposits document a less developed drainage system, of flash flood type but with less discharge than in the later episodes represented by the younger terraces. These upper deposits may be equivalent of the "Torrential deposits of Carqueija and Salabardos" areas, described upstream in the Lower Mondego (Soares et al., 1993).

The sea-level highstands during the Quaternary, that never reached the Pliocene eustatic maximum, together with regional crustal uplift and localized uplift of the Serra da Boa Viagem-Verride structure (as also suggested by Cabral, 1995) explain the transverse nature of the drainage.

Because of the important Pliocene marine transgression (assuming the eustatic maximum at $\sim 60 \mathrm{~m}$ a.s.l., according to Dowsett et al., 1996), a shore platform surface was developed in all sectors of the study area and this can be used as a geomorphic reference level to infer Quaternary active tectonics and long-term uplift. At Marinha das Ondas-Paião area (left-hand bank; Figs. 1 and 8), the base of the SLD13 is subhorizontal, at 75 to $80 \mathrm{~m}$ a.s.l. This provides a long-term crustal uplift rate (c.u.r.) of $0.004 \mathrm{~m} / \mathrm{ka}$ (75-60 m/3600 ka). However, on the SW flank of the Serra da Boa Viagem-Verride structure this surface (and coeval marine sediments that overlie it; Cunha et al., 1993; Ramos, 2008) is located at higher altitudes towards the top of this arcuate relief. So, at the Abrunheira-Samuel area (left-hand bank) the surface is at 100 to $125 \mathrm{~m}$ a.s.l. and has a c.u.r. of $0.014 \mathrm{~m} / \mathrm{ka}$. To the west of Serra São Bento (right-hand bank) the surface is at $140-150 \mathrm{~m}$ and has a c.u.r. of $0.024 \mathrm{~m} / \mathrm{ka}$. At Bandeira (the more uplifted sector of the Serra da Boa Viagem relief) the surface is at $257 \mathrm{~m}$ a.s.l. and has a c.u.r. of $0.055 \mathrm{~m} / \mathrm{ka}$. Significant differential uplift is responsible for the variation between these areas and the evidence observed at Maiorca (the tectonically depressed area north of the Serra da Boa Viagem, corresponding to the Quiaios-Alhadas-Maiorca thrust footwall bloc), where this surface is at $20 \mathrm{~m}$ a.s.l. and the resulting c.u.r. is $-0.01 \mathrm{~m} / \mathrm{ka}$ (local subsidence near the fault). The more significant uplift of the Serra da Boa Viagem-Verride structure explains the fact that on the right-hand bank the T3 terrace has the surface at $64-61 \mathrm{~m}$ a.s.l., but on the left-hand bank is at $42-35 \mathrm{~m}$ a.s.l. (Fig. 8).

The differential uplift accounts not only for the vertical displacement along the Quiaios-Alhadas-Maiorca thrust fault (WNW-ESE) but also highlights the role played by the NNW-SSE faults (e.g. the Tavarede fault: Figs. 2, 3, and 7), which acted as tear faults.

In other regions of the Portuguese coast, Cabral (1995) used the altitude of this uppermost unit and associated Pliocene marine planation surface, at up to $250-300 \mathrm{~m}$ a.s.l., to estimate a c.u.r. of $0.05-0.07 \mathrm{~m} / \mathrm{ka}$ for the last 3.6 Ma.

For a specific sector, crustal uplift rates can be estimated using different geomorphic references. As an example of a less uplifted sector, for the Armazéns-Paião area (left-hand bank; Figs. 1 and 8), a c.u.r. of $0.006 \mathrm{~m} / \mathrm{ka}$ is obtained for the last 3.6 Ma (80-60 m/3600 ka; using as 


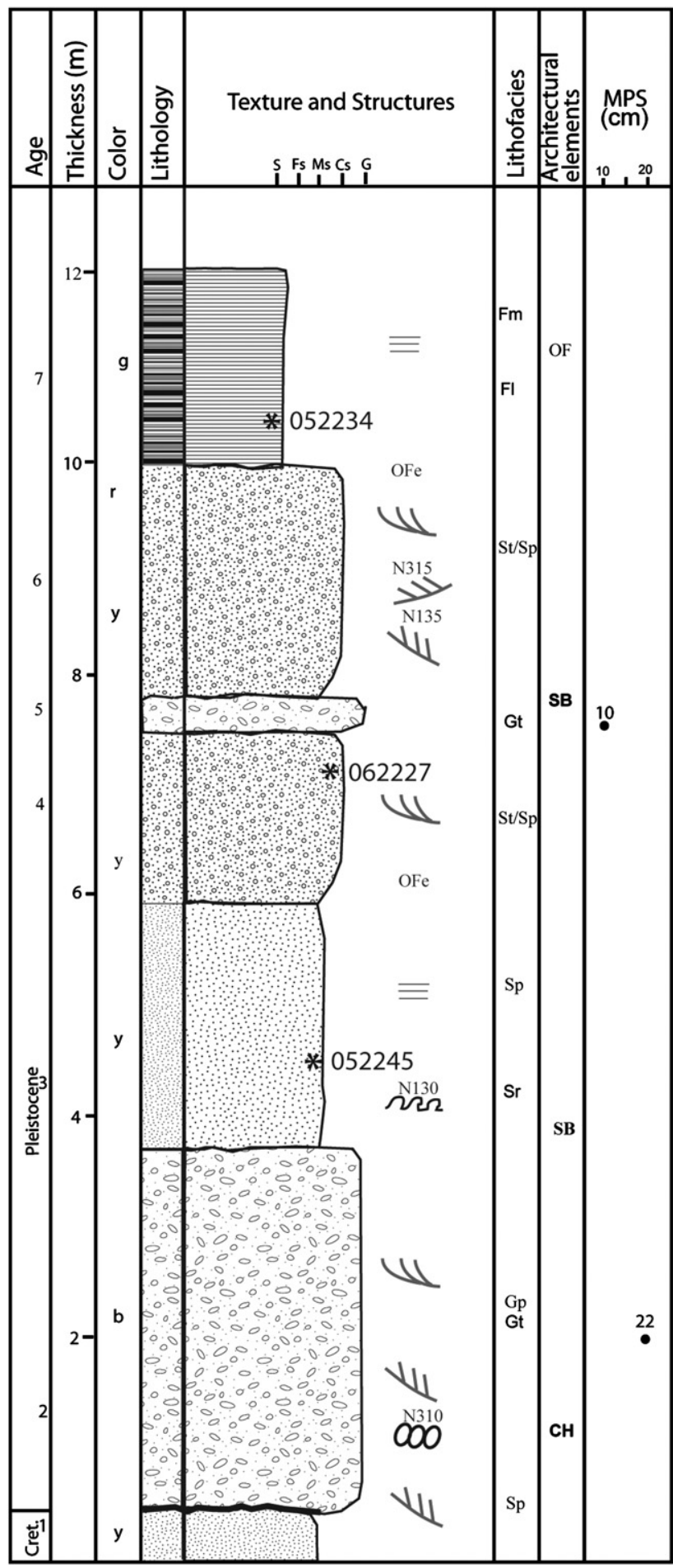

Fig. 14. Stratigraphic column at Ervidinho, representing the T4 terrace overlying Cretaceous bedrock (Cret.). OFe - iron oxides; Gp - gravel, stratified with planar crossbeds; Gt - gravel stratified with trough cross-beds; Sp - sand, fine to very coarse, may be pebbly, with planar cross-beds; St - sand, fine to very coarse, may be pebbly, with trough cross beds; $\mathrm{Sr}$ - Sand, very fine to coarse, with ripple cross lamination; Fm - massive silt; $\mathrm{Fl}$ - silt, with fine lamination; $\mathrm{CH}$ - channel; $\mathrm{SB}$ - sandy bedforms; OF - overbank fines. Sediment color: b - brown; $\mathrm{g}$ - gray; $\mathrm{y}$ - yellow; The stratigraphic location of the samples collected for luminescence dating (codes 052234, 052245 and 062227), are represented (black asterisks).

reference the dated marine base of the uppermost sedimentary unit), but $\sim 0.017 \mathrm{~m} / \mathrm{ka}$ for the last $\sim 1.8 \mathrm{Ma}$ (using as reference the surface of the uppermost sedimentary unit).

The luminescence age obtained for the basal deposits of the T5 terrace (at $6 \mathrm{~m}$ a.s.l.), considering the sea level at $+4 \mathrm{~m}$ at $120 \mathrm{ka}$, allows us to

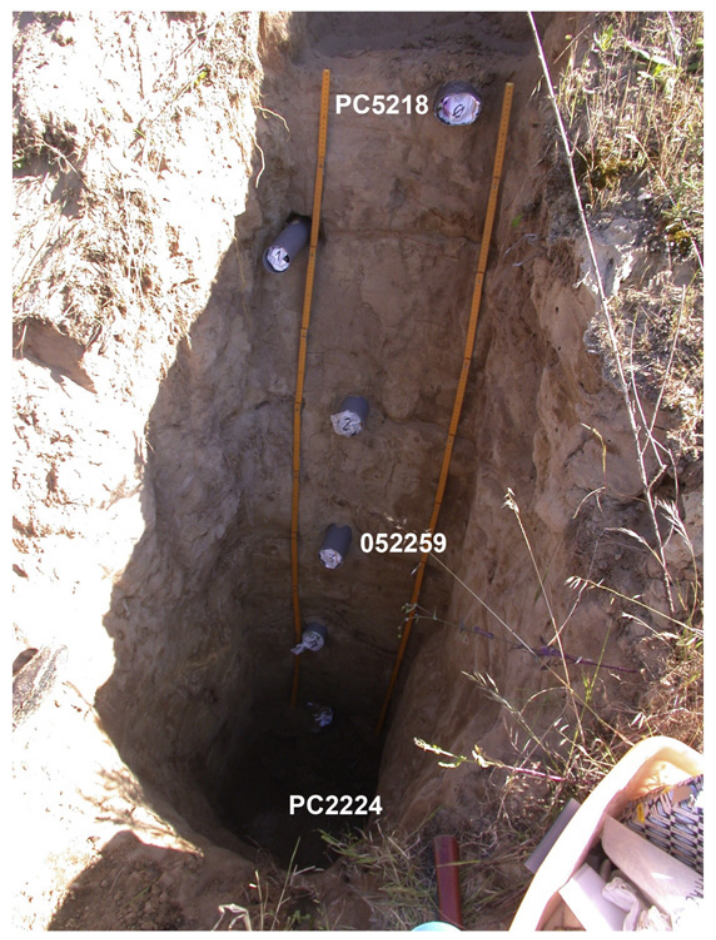

Fig. 15. Outcrop exposing the T5 terrace deposits at Armazéns site, consisting of intertidal medium to fine sands. The codes of the samples selected for luminescence dating can be seen (codes: PC5224 (base of terrace); 052259 (middle of terrace); PC5218 (top of terrace)). The rulers are $2 \mathrm{~m}$ long.

estimate a c.u.r. of $0.017 \mathrm{~m} / \mathrm{ka}$ for the last $~ 120 \mathrm{ka}(6-4 \mathrm{~m} / 120 \mathrm{ka})$ (Fig. 17). This value is similar to the ones obtained in other regions of Portugal (Cabral, 1995), except in the Extremadura coast (southern central Portugal) for which Benedetti et al. (2009) estimated that two probable raised beach deposits, dated to about $35 \mathrm{ka}$ and $42 \mathrm{ka}$, have been uplifted at rates of 0.4 to $4.3 \mathrm{~m} / \mathrm{ka}$, a surprisingly very high value for a passive continental margin. However, some very high rates of uplift have been inferred for other localized regions around the Mediterranean (see, for example, Seyrek et al., 2008, indicating rates of fluvial incision of between 0.25 and $0.40 \mathrm{~m} / \mathrm{ka}$ ).

Although the terraces in the middle and upper reaches of exorheic rivers can be related mainly to aggradation phases that occurred during the Quaternary cold stages (Trevisan, 1949; Bridgland and Westaway, 2008a, b), the terraces at river mouths, because of its position near the ocean and having intertidal and marine facies, seem clearly to be formed mainly in response to sea-level changes.

If continuous uplift is assumed, episodes of river down-cutting and aggradation in the study area can be attributed to the rise and fall of sea-level in response to global Quaternary climatic fluctuations (Shackleton and Opdyke, 1973; Shackleton et al., 1990; Bassinot et al., 1994; Cutler et al., 2003; Bridgland and Westaway, 2008a). This assumes that episodes of river aggradation and valley enlargement

Table 2

Burial depth, radionuclide concentrations and water content used for dose rate calculation of the luminescence samples.

\begin{tabular}{lllrlll}
\hline $\begin{array}{l}\text { Sample } \\
\text { code }\end{array}$ & $\begin{array}{l}\text { Depth } \\
(\mathrm{cm})\end{array}$ & $\begin{array}{l}{ }^{238} \mathrm{U} \\
\left(\mathrm{Bq} \mathrm{kg}^{-1}\right)\end{array}$ & \multicolumn{1}{l}{$\begin{array}{l}{ }^{226} \mathrm{Ra} \\
\left(\mathrm{Bq} \mathrm{kg}^{-1}\right)\end{array}$} & \multicolumn{1}{l}{${ }^{232} \mathrm{Th}^{\left(\mathrm{Bq} \mathrm{kg}^{-1}\right)}$} & $\begin{array}{l}{ }^{40} \mathrm{~K} \\
\left(\mathrm{~Bq} \mathrm{~kg}^{-1}\right)\end{array}$ & $\begin{array}{l}\text { Water content } \\
(\%)\end{array}$ \\
\cline { 2 - 7 } 052234 & 150 & $70 \pm 8$ & $88.2 \pm 1.1$ & $87.7 \pm 1.0$ & $818 \pm 11$ & 10 \\
052245 & 800 & $20 \pm 6$ & $19.0 \pm 0.5$ & $12.7 \pm 0.5$ & $520 \pm 12$ & 10 \\
052256 & 100 & $46 \pm 4$ & $40.4 \pm 0.5$ & $44.1 \pm 0.6$ & $609 \pm 9$ & 10 \\
052259 & 160 & $10 \pm 4$ & $9.0 \pm 0.4$ & $7.2 \pm 0.3$ & $316 \pm 9$ & 20 \\
PC5218 & 40 & $4 \pm 4$ & $10.2 \pm 0.3$ & $8.7 \pm 0.3$ & $332 \pm 8$ & 10 \\
PC5224 & 260 & $1 \pm 5$ & $8.9 \pm 0.4$ & $7.1 \pm 0.4$ & $327 \pm 8$ & 20 \\
062227 & 500 & $24 \pm 4$ & $20.0 \pm 0.4$ & $11.4 \pm 0.4$ & $381 \pm 8$ & 8 \\
\hline
\end{tabular}


Table 3

Summary of quartz optically stimulated luminescence. *Natural signals were in saturation (i.e. $>86 \%$ of the saturation level of the dose response curve).

\begin{tabular}{|c|c|c|c|c|c|c|c|c|c|}
\hline Code & Geomorphic level & Lithology & $\begin{array}{l}\text { Altitude } \\
(\mathrm{m})\end{array}$ & $\begin{array}{l}\text { Burial depth } \\
(\mathrm{cm})\end{array}$ & $\begin{array}{l}\mathrm{D}_{\mathrm{e}} \\
(\mathrm{Gy})\end{array}$ & $\mathrm{n}$ & $\begin{array}{l}\text { Dose rate } \\
(\mathrm{Gy} / \mathrm{ka})\end{array}$ & $\begin{array}{l}\text { Qz age } \\
\text { (ka) }\end{array}$ & Dose recovery \\
\hline $\begin{array}{l}052256 \\
\text { MOINHO-1 }\end{array}$ & Old colluvium & Clayish very fine red sand & 35 & 100 & $>200^{*}$ & 6 & $3.32 \pm 0.09$ & $>60$ & - \\
\hline $\begin{array}{l}\text { PC5218 } \\
\text { ARMAZ-0 }\end{array}$ & T5 (top) & Medium to fine white sand & 7.6 & 40 & $161 \pm 10$ & 20 & $1.47 \pm 0.06$ & $110 \pm 9$ & $\begin{array}{l}0.98 \pm 0.02 \\
(n=6)\end{array}$ \\
\hline $\begin{array}{l}052259 \\
\text { ARMAZ-1 }\end{array}$ & T5 (middle) & Medium white sand & 6 & 160 & $156 \pm 8$ & 22 & $1.24 \pm 0.05$ & $126 \pm 9$ & $\begin{array}{l}0.93 \pm 0.04 \\
(n=6)\end{array}$ \\
\hline $\begin{array}{l}\text { PC5224 } \\
\text { ARMAZ-6 }\end{array}$ & T5 (base) & Medium to fine white sand & 5.4 & 260 & $119 \pm 8$ & 15 & $1.23 \pm 0.05$ & $97 \pm 8$ & $\begin{array}{l}1.02 \pm 0.03 \\
(n=6)\end{array}$ \\
\hline
\end{tabular}

Table 4

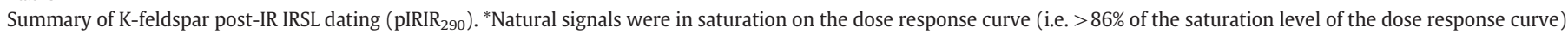
Those samples have similar dose response curves and the quoted dose corresponds to a signal at $86 \%$ of saturation and is considered a minimum value.

\begin{tabular}{|c|c|c|c|c|c|c|c|c|}
\hline Code & Geomorphic level & Lithology & $\begin{array}{l}\text { Altitude } \\
(\mathrm{m})\end{array}$ & $\begin{array}{l}\text { Burial } \\
\text { depth (cm) }\end{array}$ & $\begin{array}{l}\mathrm{D}_{\mathrm{e}} \\
(\mathrm{Gy})\end{array}$ & $\mathrm{n}$ & $\begin{array}{l}\text { Dose rate } \\
(\mathrm{Gy} / \mathrm{ka})\end{array}$ & $\begin{array}{l}\text { K-feldspar age } \\
(\mathrm{ka})\end{array}$ \\
\hline $\begin{array}{l}052256 \\
\text { MOINHO-1 }\end{array}$ & Old colluvium & Clayish very fine red sand & 35 & 100 & $217 \pm 7$ & 3 & $4.12 \pm 0.15$ & $53 \pm 3$ \\
\hline $\begin{array}{l}\text { PC5218 } \\
\text { ARMAZ-0 }\end{array}$ & T5 (top) & Medium to fine white sand & 9.6 & 40 & $237 \pm 7$ & 11 & $2.32 \pm 0.09$ & $102 \pm 5$ \\
\hline $\begin{array}{l}052259 \\
\text { ARMAZ-1 }\end{array}$ & T5 (middle) & Medium to fine white sand & 8.4 & 160 & $246 \pm 10$ & 8 & $2.10 \pm 0.08$ & $117 \pm 7$ \\
\hline $\begin{array}{l}\text { PC5224 } \\
\text { ARMAZ-6 }\end{array}$ & T5 (base) & Medium to fine white sand & 7.4 & 260 & $219 \pm 8$ & 12 & $2.08 \pm 0.08$ & $106 \pm 6$ \\
\hline $\begin{array}{l}052234 \\
\text { ERVI-2 }\end{array}$ & $\mathrm{T} 4$ (top) & Clayish silt & 20.5 & 150 & $>1000^{*}$ & 3 & $6.01 \pm 0.23$ & $>170$ \\
\hline $\begin{array}{r}062227 \\
\text { ERVI-3 }\end{array}$ & T4 (middle) & Medium yellowish sand & 17 & 500 & $>1000^{*}$ & 6 & $2.58 \pm 0.09$ & $>390$ \\
\hline $\begin{array}{l}052245 \\
\text { ERVI-1 }\end{array}$ & T4 (base) & Medium yellowish sand & 14.5 & 800 & $>1000^{*}$ & 3 & $2.93 \pm 0.11$ & $>340$ \\
\hline
\end{tabular}

occur when the valley is flooded by rising sea-level (transgressive stage) or during highstands, whilst episodes of fluvial incision are associated with low sea level (e.g. Vandenberghe, 2002; Bridgland and Westaway, 2008a). The presence of beach deposits in the distal sectors of the T5, T4 and T3 terraces (Lavos-Armazéns sector), and taking into account the available luminescence dating results, led us to assume that the T5 is related with the MIS5 ( 100 to $125 \mathrm{ka})$, T4 probably comprises the MIS7 to MIS11 ( 200 to $410 \mathrm{ka}$ ) and the T3 probably is older than $460 \mathrm{ka}$. The consolidated sandy colluvium located near Moinho do Almoxarife, dated to $53 \pm 3 \mathrm{ka}$, is a slope deposit probably related with the mild-cold and wet climate conditions that affected the western Iberia offshore region during the period 57 to $31 \mathrm{ka}$, when climate was

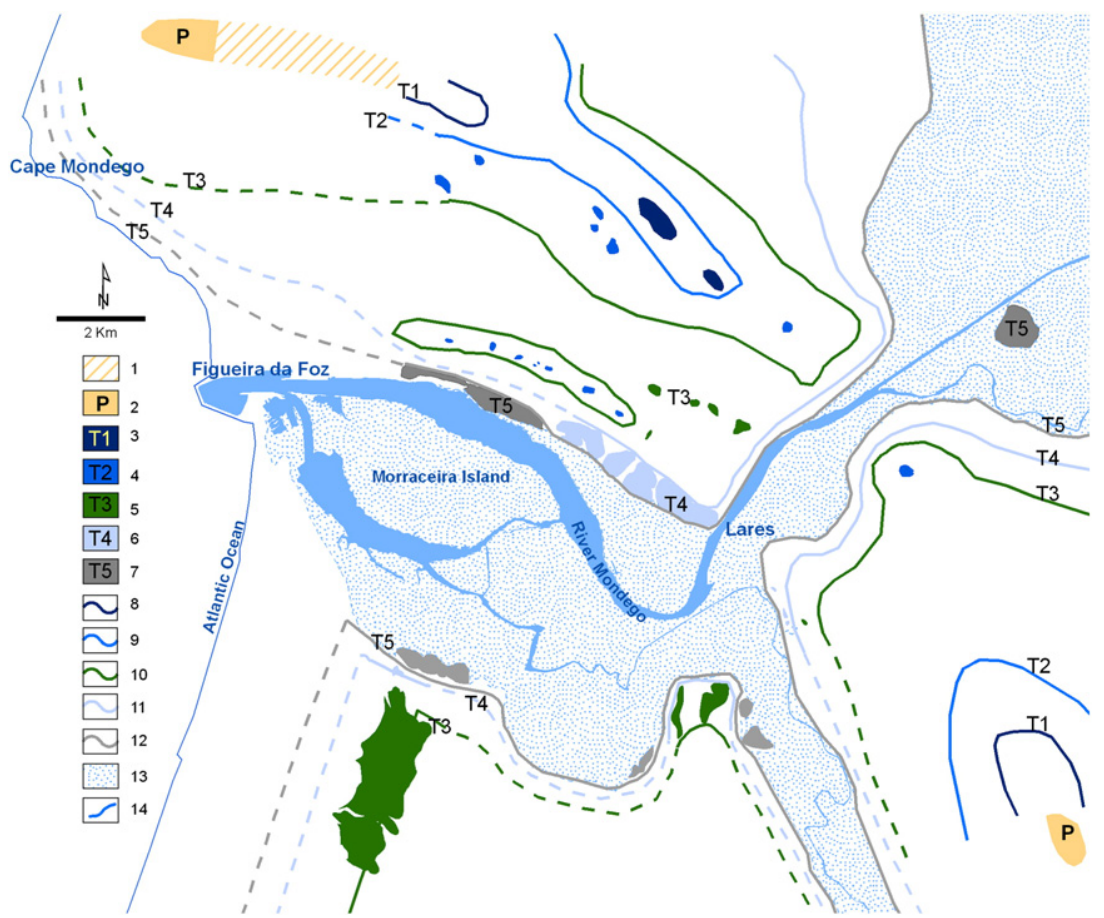

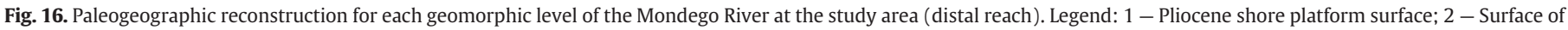

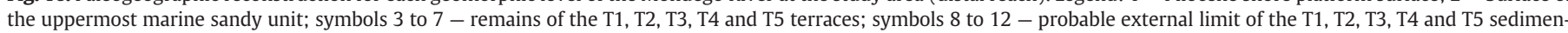
tation areas; 13 - alluvial plain; 14 - coast-line. 
characterized by a succession of mild and wet periods (interstadials) alternating with cold and dry periods (stadials), related to the Dansgaard-Oescheger (D-O) cycles (Lebreiro et al., 1996; De Abreu et al., 2003; Roucoux et al., 2005) and the coeval sea-level was significantly below the present one (at about - $60 \mathrm{~m}$; Rabineau et al., 2006).

In the future, for the older terraces, it will be necessary to use other dating to test and improve the age relationships.

The ages of the River Mondego T5 and T4 terraces seem to be similar to the ages of the Lower River Tejo (Tagus) T5 and T4 terraces (Martins et al., 2010a,b). Assuming that the age of the SLD13 surface (beginning of the incision stage) is not younger than $\sim 1.8 \mathrm{Ma}$, an age obtained by cosmogenic dating of a similar uppermost sedimentary unit at the Sierra Morena in Spain (Escudero and Olmo, 1997), the plotting of the older terraces elevations in the study area allows us to obtain by extrapolation an estimation of the ages of their surfaces: T3 as $\sim 400 \mathrm{ka}, \mathrm{T} 2$ as $\sim 700 \mathrm{ka}$ and T1 as $~ 1100 \mathrm{ka}$ (Fig. 17).

The proposed model for the formation of the River Mondego terraces in the coastal study area seems similar to the one proposed for the Lower Tejo terraces, interpreted as being related to cyclic glacio-eustatic fluctuations superimposed onto a long-term regional uplift trend (Martins et al., 2010a,b). For the modern alluvial infill (uppermost Pleistocene and Holocene) and at least the three lowest terraces (T6, T5 and T4), the periods of river aggradation seem to be coincident with sea-level highstands and milder climatic conditions, whilst the periods of fluvial incision coincide with important sea-level lowstands and cold climate conditions. This pattern of climate-eustatic related forcing of fluvial aggradation and incision is observed for many fluvial systems in NW Europe and indeed worldwide (Bridgland et al., 2007 and references therein).

\section{Conclusions}

The study area exhibits diverse landforms with structural tectonic characteristics and sedimentary evidence of fluvial to shallow marine environments, whose analysis supports the interpretation of geological processes and coeval evolution of the landscape of this coastal region during the Pleistocene. Below the uppermost lithological unit of the sedimentary infill of the basin (considered of be latest Zanclean to Gelasian in age), and above the modern floodplain ( $2 \mathrm{~m}$ a.s.l.), five terraces, represented by sedimentary deposits or straths, can be distinguished. On the right-hand bank, the respective altitudes of these terrace surfaces are: T1 at $128-125 \mathrm{~m}$; T2 at $101-90 \mathrm{~m}$; T3 at 70-60 m; T4 at 29-24 m; T5 at 11-10 m a.s.l. The staircase records successive episodes of river incision (downcutting) and then stability, followed by aggradation. Taking in account the long duration of these

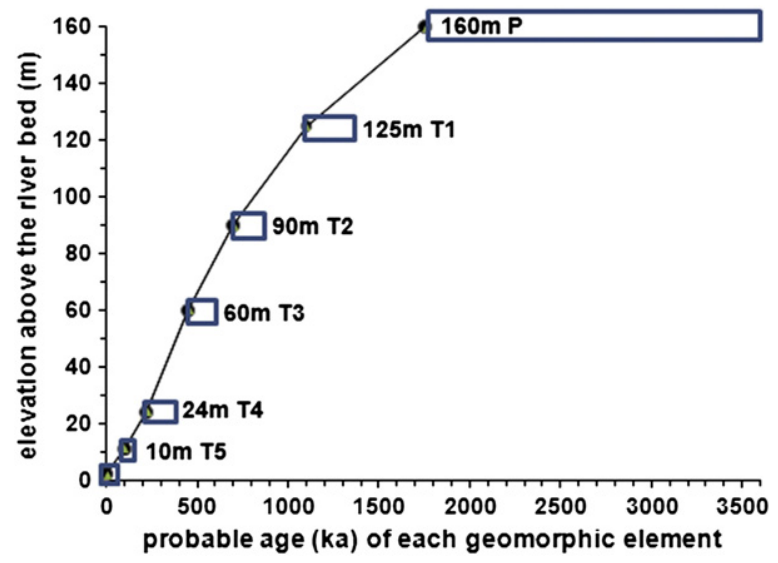

Fig. 17. For the Vila Verde-Maiorca terrace staircase (right bank), the age of the T5 terrace is plotted against height above the Mondego River bed. Assuming for the SLD13 surface an age of $\sim 1.8 \mathrm{Ma}$, the plot allows estimation of the probable ages of the older terrace surfaces: T4 at $\sim 220 \mathrm{ka}, \mathrm{T} 3$ at $\sim 460 \mathrm{ka}, \mathrm{T} 2$ at $\sim 700 \mathrm{ka}$ and T1 at $\sim 1100 \mathrm{ka}$. The rectangles represent the probable aggradation duration of each geomorphic reference level. cycles, based on the available luminescence dating, it is hypothesized that the main control of the younger terraces genesis on this coastal area should be glacio-eustasy. Episodic deep valley incision would have been determined by periods of very low sea level, namely at 200-125 ka (T4/T5; MIS6) and 100-14 ka (T5/Recent alluvial infill; MIS3 and MIS2).

This study indicates significant post-Pliocene tectonic activity, expressed by a crustal uplift rate of $0.004-0.055 \mathrm{~m} / \mathrm{ka}$ for the last 3.6 Ma. However, if we use the surface of the uppermost sedimentary unit as a geomorphic reference, the uplift rate will be of 0.017$0.118 \mathrm{~m} / \mathrm{ka}$ for the last $\sim 1.8 \mathrm{Ma}$. The highest uplift is at the western sector of the Serra da Boa Viagem-Verride structure (Quiaios fault upthrust block). The activity the Quiaios-Alhadas-Maiorca thrust fault (during the Quaternary) and its consequences on the drainage directions on the Serra da Boa Viagem are evident; the tilting of the relief towards the south and the development of transverse drainage across bedrock structures, forming cuestas, are related. The probably active faults and lineaments have the following main directions: WNW-ESE, N-S, NESW and NNW-SSE; they are involved in the differential uplift of the region.

\section{Acknowledgments}

This work is within the scope of the post-doctoral scholarship to A. Ramos (ref: SFRH/BPD/63547/2009/J0051452L78Y) and of project PTDC/CTE-GIN/66283/2006, both approved by the Fundação para a Ciência e Tecnologia and co-funded by the FEDER. Research was supported by the IMAR-CMA-University of Coimbra, GEGOT and CGUC (Portugal), and both Aarhus University and Risø DTU (Denmark). The stay of P. Cunha at Risø DTU was supported by the Fundação para a Ciência e a Tecnologia (Sabbatical grant). We also thank João Cabral (Univ. Lisboa) and L. Gama Pereira (Univ. Coimbra), for their constructive comments, and the journal reviewers, D.R. Bridgland (Durham University), António Martins (Univ. Évora), Martin Stokes (Univ. Plymouth) and A.J. Plater (Univ. Liverpool), whose comments significantly improved the manuscript.

\section{References}

Almeida, A.C., 1997. Dunas de Quiaios Gândara e Serra da Boa Viagem, uma abordagem ecológica da paisagem. Fundação Calouste Gulbenkian, JNICT, Coimbra. 321 pp.

Almeida, A.C., 2001. A carsificação da Serra da Boa Viagem, um processo quaternário. Estudos do Quaternário 4, 211-233.

Almeida, A.C., Soares, A.F., Cunha, L., Marques, J.F., 1990. Proémio ao estudo do Baixo Mondego. Biblos 66, 17-47.

André, J.N., 1996. Morfologia litoral da área compreendida entre o Cabo Mondego e S. Pedro de Moel. MSc thesis, Univ. Coimbra, Portugal, 164 pp.

André,J.N., Cunha, P.P., Dinis, J., Dinis, P., Cordeiro, F., 2009. Características geomorfológicas e interpretação da evolução do campo dunar eólico na zona costeira entre a Figueira da Foz e a Nazaré. Pub. Assoc. Portuguesa de Geomorfólogos, 4, pp. 311-344.

Barbosa, B.P., Soares, A.F., Rocha, R.B., Manuppella, G., Henriques, M.H., 1988. Notícia explicativa da folha 111-A (Cantanhede), da carta geológica de Portugal na escala 1/50.000. Serviços Geológicos de Portugal. Lisboa, 46 pp.

Bassinot, F.C., Labeyrie, L.D., Vincent, E., Quidelleur, X., Shackleton, N.J., Lancelot, Y., 1994. The astronomical theory of climate and the age of the Brunhes-Matuyama magnetic reversal. Earth and Planetary Science Letters 126, 91-108.

Benedetti, M.M., Haws, J.A., Funk, C.L., Daniels, J.M., Hesp, P.A., Bicho, N.F., Minckley, T.A., Ellwood, B.B., Forman, S.L., 2009. Late Peistocene raised besches of coastal Estremadura, central Portugal. Quaternary Science Reviews 28, 3428-3447.

Bezzeghoud, M., Fitas, A.J.S., Borges, J.F., Carrilho, F., Senos, M.L., 2000. Sismicidade, mecanismos focais e parâmetros da fonte no sul de Portugal. Abstract. $2^{\mathrm{a}}$ Assembleia Luso-Espanhola de Geodesia e Geofísica, Lagos (Algarve, Portugal), 8-12 Fev, pp. 129-130.

Blum, M.D., Törnqvist, T.E., 2000. Fluvial responses to climate and sea-level change: a review and look forward. Sedimentology 47, 2-48.

Bøtter-Jensen, L., Andersen, C.E., Duller, G.A.T., Murray, A.S., 2003. Developments in radiation, stimulation and observation facilities in luminescence measurements. Radiation Measurements 37, 535-541.

Bridgland, D.R., Keen, D.H., Westaway, R., 2007. Global correlation of Late Cenozoic fluvial deposits: a synthesis of data from IGCP 449. Quaternary Science Reviews 26, 2694-2700.

Bridgland, D.R., Westaway, R., 2008a. Climatically controlled river terrace staircases: a worldwide Quaternary phenomenon. Geomorphology 98, 285-315. 
Bridgland, D.R., Westaway, R., 2008b. Preservation patterns of Late Cenozoic fluvial deposits and their implications: results from IGCP 449. Quaternary International 198 5-38.

Buylaert, J.-P., Jain, M., Murray, A.S., Thomsen, K.J., Thiel, C., Sohbati, R., 2012. A robust feldspar luminescence dating method for Middle and Late Pleistocene sediments. Boreas. doi:10.1111/j.1502-3885.2012.00248.x.

C.C.D.R.C. - Comissão Coordenação e Desenvolvimento Regional do Centro, 2000 Plano de Bacia Hidrográfica do Rio Mondego. Análise Biofísica, Coimbra 252 pp.

Cabral, J., 1995. Neotectónica em Portugal Continental. Memórias do Instituto Geológico e Mineiro, 31. Portugal, 265 pp.

Cabral, J., Ribeiro, A., 1988. Carta Neotectónica de Portugal na escala 1/1000000. Servicos Geológicos de Portugal.

Cachão, M.A., 1989. Contribuição para o estudo do pliocénico marinho português (sector Pombal-Marinha Grande) - Micropaleontologia e biostratigrafia. Provas Apt. Ped. Cap. Cient., Fac. Ciên. Univ, Lisboa. 204 pp.

Carvalho, G.S., 1949. Les depôts des terraces et la paléogéographie du pliocène dans la bordure Meso-Cenozóique occidental du Portugal (entre le Vouga et le Mondego). Memórias e Notícias. Publ. Mus. Lab. Min. Geol. Univ. Coimbra, 25, pp. 3-27.

Carvalho, G.S., 1952. Les dépots détritique plio-pleistocènes et la morphologie de la Gândara au Nord de la Serra da Boa Viagem (Portugal). Révue de Géomorphologie Dynamique 6, 275-294.

Carvalho, G.S., 1955. Nouvelles observations sur la sédimentologie dês dépôts plioquaternaires de l'embouchure du Mondego (Portugal). Memórias e Notícias, Pub. Museu Mineralógico e Geológico. Univ. Coimbra, 311, pp. 13-25.

Carvalho, G.S., 1964. Areias da Gândara (Portugal) - uma formação eólica Quaternária. Publicações Museu e Laboratório Mineralógico e Geológico: Faculdade Ciências Univ. Porto, 81, pp. 7-32. $4^{\mathrm{a}}$ sér.,.

Cunha, L., Almeida, A.C., 2008. António Ferreira Soares e a Gemorfologia do Baixo Mondego. A Terra: conflitos e ordem: Homenagem ao professor Ferreira Soares, Coimbra, Portugal, pp. 17-24.

Cunha, L., Soares, A.F., 1997. Alguns problemas geomorfológicos no sector oriental do Baixo Mondego. O confronto de morfologias nas áreas de Coimbra e de Condeixa. Actas do Seminário: O Baixo Mondego - Organização geossistémica e recursos naturais, Coimbra, Portugal, pp. 41-49.

Cunha, L., Soares, A.F., Tavares, A., Marques, J.F., 1999. O julgamento geomorfológico de Coimbra. 0 testemunho dos depósitos quaternários. Actas 10 Col. Geografia Coimbra. Cadernos de Geografia. Num. Esp, pp. 15-26.

Cunha, P.P., Barbosa, B.P., Reis, R.P., 1993. Synthesis of the Piacenzian onshore record between the Aveiro and Setúbal parallels (Western Portuguese margin). Ciências da Terra, 12. Universidade Nova de Lisboa, Portugal, pp. 35-43.

Cunha, P.P., Pinto, J., Dinis, J.L., 1997. Evolução da fisiografia e ocupação antrópica na área estuarina do Rio Mondego e região envolvente (Portugal centro-oeste) desde 1947. Territorium 4, 99-124.

Cunha, P.P., Campar, A., Ramos, A., Cunha, L., Dinis, J., 2005. Geomorphology and coastal dynamics of the Figueira da Foz region. In: Ramos-Pereira, A., Trindade, J., Neves, M. (Eds.), Sixth International Conference on Geomorphology. Field trip guide. Zaragoza, pp. 19-28.

Cunha, P.P., Martins, A.A., Huot, S., Murray, A.S., Raposo, L., 2008. Dating the Tejo River lower terraces in the Ródão area (Portugal) to assess the role of tectonics and uplift. Geomorphology 102, 43-54

Cunha, P.P., Almeida, N.A.C., Aubry, T., Martins, A.A., Murray, A.S., Buylaert, J.-P., Sohbati, R., Raposo, L., Rocha, L., 2012. Records of human occupation from Pleistocene river terrace and aeolian sediments in the Arneiro depression (Lower Tejo River, central eastern Portugal). Geomorphology. doi:10.1016/j.geomorph.2012.02.017.

Cutler, K.B., Edwards, R.L., Taylor, F.W., Cheng, H., Adkins, J., Gallup, C.D., Cutler, P.M., Burr, G.S., Bloom, A.L., 2003. Rapid sea-level fall and deep-ocean temperature change since the last interglacial period. Earth and Planetary Science Letters 206, 253-271.

Danielsen, R., 2008. Palaeoecologial development of the Quiaios-Mira dunes, northern central littoral. Portugal. Review of Palaeobotany and Palynology 152 (1-2) 74-99.

De Abreu, L., Shackleton, N.J., Schönfeld, J., Hall, M., Chapman, M.R., 2003. Millennialscale oceanic climate variability off the Western Iberian margin during the last two glacial periods. Marine Geology 196, 1-20.

De Vicente, G., Cloetingh, S., Van Wees, J.D., Cunha, P.P., 2011. Tectonic classification of Cenozoic Iberian foreland basins. Tectonophysics 502 (1-2), 38-61.

Dowsett, H.J., Barron, J.A., Poore, R.Z., 1996. Middle Pliocene sea surface temperatures: a global reconstitution. Marine Micropaleontology 27, 13-25.

Duller, G.A.T., 2004. Luminescence dating of Quaternary sediments: recent advances. Journal of Quaternary Science 19, 183-192.

Escudero, B., Olmo, D., 1997. Resultados paleomagnéticos de la raña del Hespérico Meridional (Montoro, Córdoba). Geogaceta 21, 31-34.

Gibbard, P.L., Lewin, J., 2009. River incision and terrace formation in the Late Cenozoic of Europe. Tectonophysics 474, 41-55.

Huntley, D.J., Baril, M.R., 1997. The K content of the K-feldspars being measured in optical dating or in thermoluminescence dating. Ancient TL 15, 11-13.

Lebreiro, S.M., Moreno, J.C., McCave, I.N., Weaver, P.P.E., 1996. Evidence for the Heinrich layers off Portugal (Tore Seamount: 391N, 121W). Marine Geology 131, 47-56.

Lewin, J., Gibbard, P.L., 2010. Quaternary river terraces in England: forms, sediments and processes. Geomorphology 120, 293-311.

Martins, A.A., Cunha, P.P., Huot, S., Murray, A.S., Buylaert, J.-P., 2009. Geomorphological correlation of the tectonically displaced Tejo River terraces (Gavião-Chamusca area, central Portugal) supported by luminescence dating. Quaternary International 199, 75-91.

Martins, A.A., Cunha, P.P., Buylaert, J.P., Huot, S., Murray, A.S., Dinis, P., Stokes, M., 2010a. K-feldspar IRSL dating of a Pleistocene river terrace sequence of the Lower Tejo River (Portugal, western Iberia). Quaternary Geochronology 5, 176-180.
Martins, A.A., Cunha, P.P., Rosina, P., Oosterbeck, L., Cura, S., Grimaldi, S., Gomes, J., Buylaert, J.-P., Murray, A.S., Matos, J., 2010b. Geoarchaeology of Pleistocene open-air sites in the Vila Nova da Barquinha-Santa Cita area (Lower Tejo Rive basin, central Portugal). Proceedings of the Geologists' Association 121 (2), 128-140.

Miall, A.D., 1996. The Geology of Fluvial Deposits: Sedimentary Facies, Basin Analysis, and Petroleum Geology. Springer. 582 pp.

Murray, A.S., 1996. Developments in optically transferred luminescence and phototransferred thermoluminescence dating: application to a 2000-year sequence of flood deposits. Geochimica et Cosmochimica Acta 60, 565-576.

Murray, A.S., Funder, S., 2003. OSL dating of a Danish coastal marine deposit: a test of accuracy. Quaternary Science Reviews 22, 1177-1183.

Murray, A.S., Wintle, A.G., 2003. The single aliquot regenerative dose protocol: potential for improvements in reliability. Radiation Measurements 37, 377-381.

Murray, A.S., Marten, R., Johnston, A., Martin, P., 1987. Analysis for naturally occurring radionuclides at environmental concentrations by gamma spectrometry. Journal of Radioanalytical and Nuclear Chemistry 115, 263-288.

Murray, A.S., Svendsen, J.I., Mangerud, J., Astakhov, V.I., 2007. Testing the accuracy of quartz OSL dating using a known-age Eemian site on the river Sula, northern Russia. Quaternary Geochronology 2, 102-109.

Noivo, L.M.S., 1996. Morfologia e dinâmica sedimentar das dunas de Quiaios. MSc thesis. Univ. Aveiro. Portugal. 172 pp.

Olley, J.M., Murray, A.S., Roberts, R.G., 1996. The effects of disequilibria in the uranium and thorium decay chains on burial dose rates in fluvial sediments. Quaternary Science Reviews 15, 751-760.

Pais, J., Cunha, P.P., Pereira, D., Legoinha, P., Dias, R., Moura, D., BrumdaSilveira, A. Kullberg, J.C., González-Delgado, J.A. 2012. The Paleogene and Neogene of Western Iberia (Portugal), A Cenozoic Record in the European Atlantic Domain, 1st Edition. Springer Briefs in Earth Sciences, Springer, Series ID: 88117, 1. 158 pp.

Rabineau, M., Berné, S., Olivet, J.-L., Aslanian, D., Guillocheau, F., Joseph, P., 2006. Earth and Planetary Science Letters 252, 119-137.

Ramos, A.M., 2000. Organização e significado dos depósitos mais recentes do estuário do rio Mondego. MSc. thesis. Univ. Coimbra. Portugal. 200 pp.

Ramos, A.M., 2008. O Pliocénico e o Plistocénico da Plataforma Litoral entre os paralelos do Cabo Mondego e da Nazaré. PhD thesis, Univ. Coimbra, Portugal. 329 p.

Ribeiro, O., Patrício, A., 1943. Nótula sobre os terraços do Mondego nos arredores de Coimbra. Ass. Port. Progr. Ciências, 40 Congr., t, 4, pp. 248-270.

Ribeiro, A., Antunes, M., Rocha, R., Soares, A.F., Zbyszewski, G., Moitinho de Almeida, F., Carvalho, D., Monteiro, J., 1979. Introdution à la géologie générale du Portugal. Serviços Geológicos de Portugal, Portugal. 114 p.

Ribeiro, A., Cabral, J., Batista, R., Matias, L., 1996. Stress pattern in Portugal mainland and the adjacent Atlantic region, West Iberia. Tectonics 15, 641-659.

Rocha, R.B., Manuppella, G., Mouterde, R., Ruget, C., Zbyszewski, G., 1981 - Carta geológica de Portugal na escala 1/50000. Notícia explicativa da folha 111-C (Figueira da Foz). Serviços Geológicos de Portugal. Portugal, $126 \mathrm{pp}$.

Roucoux, K.H., de Abreu, L., Shackleton, N.J., Tzedakis, P.C., 2005. The response of NW Iberian vegetation to North Atlantic climate oscillations during the last $65 \mathrm{kyr}$ Quaternary Science Reviews 24, 1637-1653.

Santos, J.A.B., 2009. Geomorfologia Fluvial e Evolução Quaternária da Bacia do Mondego PhD Thesis, Univ. Coimbra, Portugal, 307 p.

Seyrek, A., Demir, T., Pringle, M., Yurtmen, S., Westaway, R., Bridgland, D., Beck, A. Rowbothan, G., 2008. Late Cenozoic uplift of the Amanos Mountains and incision of the Middle Ceyhan river gorge, southern Turkey; $\mathrm{Ar}-\mathrm{Ar}$ dating of the Düziçi basalt. Geomorphology 117, 321-355.

Shackleton, N.J., Opdyke, N.D., 1973. Oxygen isotope and palaeomagnetic stratigraphy of Equatorial Pacific Core V28-238, oxygen isotope temperatures and ice volumes on a 105 year-106 year scale. Quaternary Research 3, 39-55.

Shackleton, N.J., Berger, A., Peltier, W.R., 1990. An alternative astronomical calibration of the lower Pleistocene timescale based on ODP site 677. Transactions of the Royal Society of Edinburgh 81, 252-261.

Silva, C.M., 2001. Gastrópodes Pliocénicos Marinhos de Portugal. Sistemática, Paleoecologia, Paleobiologia, Paleobiogeografia. PhD Thesis, Univ. Lisboa, Portugal, $747 \mathrm{p}$.

Silva, C.M., Landau, B., Domènech, R., Martinell, J., 2010. Pliocene Atlantic molluscan assemblages from the Mondego Basin (Portugal): age and palaeoceanographic implications. Palaeogeography, Palaeoclimatology, Palaeoecology 285, 248-254.

Soares, A.F., 1966. Estudo das formações pós-jurássicas das regiões de entre SargentoMor e Montemor-o-Velho (margem direita do Rio Mondego). Memórias e Notícias, Museu Laboratório Mineralógico Geológico Univ. Coimbra. 62, 1-343, 1 map.

Soares, A.F., 1999. As unidades quaternárias e pliocénicas no espaço do Baixo Mondego (uma perspectiva de ordem). Estudos do Quaternário 2, 7-17.

Soares, A.F., Callapez, P.M., Marques, J.F., 2007. The Farol Deposit (Depósito do Farol) a Pleistocene beach deposit from Cape Mondego (Figueira da Foz, West Central Portugal). Ciências da Terra 16, 163-173.

Soares, A.F., Cunha, P.P., Dinis, P.A., 2010. Um olhar geomorfológico pelos espaços do Baixo Mondego e do Cértima. In: Neiva, J.M.C., Ribeiro, A., Victor, M., Noronha, F. Ramalho, M. (Eds.), Ciências Geológicas: Ensino, Investigação e sua História. Associação Portuguesa de Geólogos, I. Sociedade Geológica de Portugal, Lisboa, Portugal, pp. 501-506.

Soares, A.F., Cunha, L., Marques, J.F., 1989. Depósitos quaternários do Baixo Mondego. Tentativa de coordenação morfogenética: Actas II Reunião do Quaternário Ibérico Madrid, Espanha, pp. 803-812.

Soares, A.F., Ramos, A.M., Marques, J.F., 1998. Os depósitos mais recentes da margem direita do Mondego. Cadernos de Geografia 17, 73-79.

Soares, A.F., Cunha, L., Marques, J.F., Almeida, A.C., Lapa, M.R., 1993. Depósitos de vertente do Cabo Mondego - Integração no modelo evolutivo do Quaternário do Baixo Mondego. Actas. III reunião do Quaternário Ibérico. Coimbra, Portugal, pp. 199-208. 
Soares, A.F., Cunha, L.S., Marques, J.F., 1997. Les tufs calcaires de Condeixa. Présentation générale et encadrement dans le modele géomorphologique de l'évolution de la région du Bas Mondego (Portugal). Étude Géog. Physique, 26, pp. 55-58. supll. no.

Thomsen, K.J., Murray, A.S., Jain, M., 2011. Stability of IRSL signals from sedimentary K-feldspar samples. Geochronometria 38, 1-13.

Trevisan, C., 1949. Gènese de terrasses fluviatiles en relation avec les cycles climatiques. Compt. Rendu Congr. Intern. Geogr. Lisbonne, 2, pp. 511-528.

Vandenberghe, J., 2002. The relation between climate and river processes, landforms and deposits during the Quaternary. Quaternary International 111, 17-23.
Westaway, R., Bridgland, D.R., Sinha, R., Demir, T., 2009. Fluvial sequences as evidence for landscape and climatic evolution in the Late Cenozoic: a synthesis of data from IGCP 518. Global and Planetary Change 68, 237-253.

Wintle, A.G., Murray, A.S., 2006. A review of quartz optically stimulated luminescence characteristics and their relevance in single-aliquot regeneration dating protocols. Radiation Measurements 41, 369-391. 